\title{
The Impact of Immigration on the Structure of Wages: Theory and Evidence from Britain
}

\author{
Marco Manacorda \\ Department of Economics Queen Mary University of London, CEP (LSE), CEPR and IZA
}

Alan Manning

Department of Economics London School of Economics, CEP (LSE)

Jonathan Wadsworth

Department of Economics Royal Holloway College University of London, CEP (LSE), CREAM and IZA

August 2010

Immigration to the UK, particularly among more educated workers, has risen appreciably over the past 30 years and as such has raised labor supply. However studies of the impact of immigration have failed to find any significant effect on the wages of native-born workers in the UK. This is potentially puzzling since there is evidence that changes in the supply of educated natives have had significant effects on their wages. Using a pooled time series of British crosssectional micro data on male wages and employment from the mid-1970s to the mid-2000s, this paper offers one possible resolution to this puzzle, namely that in the UK natives and foreign born workers are imperfect substitutes. We show that immigration has primarily reduced the wages of immigrants - and in particular of university educated immigrants - with little discernable effect on the wages of the native-born.

JEL Classification No. J6

Key Words: Wages, Returns to education, Immigration

We are grateful for comments and suggestions to David Card, Christian Dustmann, Steve Machin, John Van Reenen, three anonymous referees, the editor Orazio Attanasio, and seminar participants at the LSE, the Institute for Economic Analysis, Barcelona, the UNDP Human Development Report Office and the UCL-CREAM Conference on "Immigration: Impacts, Integration and Intergenerational Issues". Corresponding Author: Marco Manacorda, Centre for Economic Performance, London School of Economics, London WC2A 2AE, Tel: +44 (0)207 9556647 , E-mail: m.manacorda@1se.ac.uk 


\section{INTRODUCTION}

One of the most significant developments in the UK over the past fifteen years has been the large rise in the numbers of individuals coming to live and work there. By the mid $2000 \mathrm{~s}, 12 \%$ of the working age population had been born overseas, up from the $7.5 \%$ share observed at the end of the last recession in 1993 and the 7\% share observed in the mid-seventies (see Figure 1). The addition to the UK labor force over this period caused by the rise in the number of working age immigrants, from 2.3 to 4.2 million, is similar to that stemming from the increase in the nativeborn working age population caused by the baby boom generation reaching adulthood in the previous decade (up from 29.5 to 31.3 million). Rising immigration is also common to many industrialised countries, where the average share of immigrants in the labor force has increased from $4.3 \%$ to $7.2 \%$ between 1995 and 2005 , (OECD 2006). ${ }^{1}$

These trends have stimulated renewed interest among policy makers and academic researchers concerned with the effects of immigration. The impact of immigration on labor market outcomes is a controversial issue. The largest body of evidence comes from the United States, where different researchers have come to different conclusions about its effects. Card (1990, 2001, 2005) finds little discernible impact of immigration on natives' wages, while Borjas, Freeman and Katz (1996) and Borjas $(1999,2003)$ argue that immigration has had a pronounced effect on the native wage structure.

British evidence on the impact of immigration is rather scarce and one should not automatically assume that the impact of immigration in the UK is similar to that in the US. Not only is immigration likely to lead to different labor market effects depending on prevailing labor market institutions (Angrist and Kugler, 2003) but, unlike in the US, immigrants to the UK are, on average, better educated than the native-born and increasingly so. One notable UK study by Dustmann, Fabbri and Preston. (2005) uses variation in the composition of immigrants relative to natives by skill and region, concluding that immigration has no discernible effect on the average

1 The countries included are: Austria, Belgium, Denmark, France, Germany, Ireland, Italy, Luxembourg, the Netherlands, Norway, Portugal, Spain, Sweden, Switzerland and the United Kingdom. 
level of native wages. A similar conclusion is reached by Dustmann, Frattini and Preston. (2008), although they find some negative effect of immigration among native wages at the bottom of the distribution and a positive effect among those at the top.

Yet the finding that - on average - immigration appears not to affect the wages of natives is somewhat puzzling. The failure of a shock to UK labor supply caused by immigration to produce any discernible effect on the level and the structure of wages is hard to reconcile with a simple model of the labor market. When immigration is skill biased, as in the UK, one would also expect different effects on the wages and employment across native workers with different skills. Indeed Card and Lemieux (2001) find that - as in the US and Canada - the return to university graduates relative to those with secondary education in Britain is sensitive to the relative supply of more educated workers. This is particularly evident among age cohorts with university graduation rates above or below the long-term average trend, implying the existence of some imperfect substitutability between workers of different ages.

In this paper we offer a possible resolution to this apparent puzzle. Starting from the multi-level CES production function approach used by Card and Lemieux (2001) to assess the contribution of changes in the supply and demand for skills on the wage structure, we extend the approach by allowing for the possibility that, within each age-education group, native and immigrant workers are imperfect substitutes in production. Indeed, our empirical analysis shows that native-born and immigrant workers in the UK are far from perfect substitutes in production, so that the native-immigrant wage differential is sensitive to the share of immigrants in the working age population.

This finding can help us to understand how the wage structure has changed in the UK in recent years. We document a large rise in the share of university graduates among the 1960s birth cohort of immigrants who entered the UK in the early 1990s, (see Figure 1). This was most likely due to a combination of pull factors for skilled immigrants, namely high and rising returns to skills in the UK compared to elsewhere (especially the European Union) and push factors, 
stemming from changes in immigration policy and the recession of the early 1990s, which curbed less skilled immigration somewhat. Immigrants to the UK have increasingly become more educated than the native born, partly as a result of Britain's membership of the European Union which imposes strict curbs on immigration from outside the EU - and partly because of domestic policy decisions restricting the non-EU inflow to skilled labor, their dependents and students. ${ }^{2}$ We show that the rapid rise in highly educated immigration in turn led to a rapid deterioration in immigrants' return to college education compared to that for natives. Natives and, to some extent long term immigrants, were essentially cushioned from such a shock due to imperfect substitutability with newly arrived immigrants.

In the final part of the paper we use these estimates to compute the overall effect of increased immigration on the wage structure of natives. We show that immigration over the last thirty years has had, on average, little discernible effect on the wages of natives. Our estimates suggest that the only sizeable effect of increased immigration is on the wages of existing immigrants.

Other authors have followed a similar approach. In particular, parallel analyses to ours on the effects of immigration to the US (Card, 2009, Ottaviano and Peri, 2010) find evidence in favor of high but imperfect substitutability between immigrants and natives within age-education groups, although this finding is far from undisputed (Jaeger, 2007; Aydemir and Borjas, 2006a; Borjas, Grogger and Hanson 2008). ${ }^{3}$ In the empirical analysis below we also attempt to address some of the econometric and data issues that appear to be contentious in the debate about the degree of substitutability between immigrants and natives in the US.

The structure of the paper is as follows. Section 1 introduces the data used in the rest of the analysis and Section 2 presents basic descriptive statistics. Section 3 describes the model of

\footnotetext{
${ }^{2}$ For more discussion on this, see Bell (1997), Dustmann and Fabbri (2005) and Schmitt and Wadsworth (2007).

${ }^{3}$ Others (Grossman, 1982, Chiswick, Chiswick and Miller, 1985, Borjas, 1987) have explicitly attempted to identify the elasticity of substitution between immigrant and native workers but, differently from us, these papers treat workers with different skills as perfect substitutes. Lalonde and Topel (1991) is an exception but focuses on the extent of substitution within the stock of immigrants.
} 
wage determination underlying our empirical approach and section 4 highlights the empirical strategy based on this theoretical model and discusses identification and specification issues. The results of the regression analysis and robustness checks are given in Section 5. Section 6 presents some computations of the effects of immigration on the wage distribution based on the estimated parameters in Section 5 and the trends in Section 2 and Section 6 concludes.

\section{DATA}

The analysis is based on information on the wages and employment of natives and immigrants (defined hereafter as individuals born abroad) contained in the UK Labour Force Survey (LFS) and the General Household Survey (GHS), covering the period from the mid 1970s to the mid 2000s. The GHS (and the LFS after 1983) also contain information on year of arrival into Britain that we use later to distinguish between recent and earlier immigrants.

The LFS is the larger sample - with around 100,000 annual observations between 1975 and 1991 and around 320,000 annual observations thereafter. However, data on wages are only available from 1993. In contrast, the annual GHS is one-tenth the size, but has the advantage of containing wage information since 1973. Since our aim is to assess the effect of exogenous changes in the supply of immigrants on the wage structure, we need a measure of immigrant labor supply that is as free as possible of measurement error that would otherwise attenuate the estimate of immigration on the wage structure, a problem also highlighted by Aydemir and Borjas (2006b). For this reason and in order to have as long a sample period as possible, we groups individuals into cells based on age, education, immigrant status and time, use the GHS to estimate wage averages for each cell and merge these with the estimates of native and immigrant populations for the same cells based on the larger LFS, (see Appendix for more details).

The main sample used for estimation is men aged 26-60, although we also provide results for samples that include women. In computing wages we use only full-time workers and exclude students. Our measure of wages is gross weekly earnings. To measure labor supply we use 
population rather than employment or hours, since non-employment is non-trivial among some groups and this could itself be an effect of immigration (see Angrist and Kugler, 2003, for evidence of an effect of immigration on employment rates). ${ }^{4}$ However we test the robustness of our results to an alternative measure of labor supply.

As in Card and Lemieux (2001) and Card (2009) but unlike in Borjas (2003) and Ottaviano and Peri (2010), we use two education groups: university ("college" in the US) and secondary ("high-school" in the US). Similar to Saleheen and Shadforth (2006) we define those who left full-time education from age of 16 to 20 as a "Secondary" worker and anyone who left education at age 21 or later as a "University graduate". ${ }^{5}$ In line with convention in this area, we give those with less than secondary education (who left education before the age of 16) a lower weight in defining the supply of "secondary equivalents", to reflect the fact that, although they are assumed to be perfect substitutes for secondary workers, they have lower productivity. We probe the robustness of our results to a more detailed educational classification and to variations in the school leaving age used to define the cut-off across education groups.

To keep the analysis as consistent as possible with Card and Lemieux (2001), we group individuals into five year and five year-age cells. The mid-points of the time intervals are 1975, 1980, 1985, 1990, 1995, 2000 and 2005. Similarly the mid-points of the age intervals are 28, 33, $38,43,48,53$, and 58. We also present results below which group individuals into three rather than five year cells. The data appendix gives more information on the sample, the definition of variables, and the procedure used to compute returns to education, native-immigrant wage gaps and labor supply in terms of education equivalents. The appendix also describes how we construct cells that aggregate individuals from contiguous years into larger age and time cells.

\footnotetext{
${ }^{4}$ Dustmann and Fabbri (2005) document pronounced differences in employment between (non-white) immigrants and native born individuals. One explanation is that this might be due to language difficulties (on this see also Dustmann and Fabbri, 2003).

${ }^{5}$ Ottaviano and Peri (2010) also present robustness checks that prove the robustness of their estimated elasticity of substitution between education groups to the number of such groups.
} 


\section{DESCRIPTIVE EVIDENCE}

The first panel of Table 1 shows the increase in the ratio of immigrants to natives in the male population over time, up from 0.081 in 1975 to 0.127 in 2005 . Most of this increase occurred after 1995 as can be seen from Figure $1 .^{6}$ Table 1 and Figure 1 also show that both the level of, and the increase in, the immigration share is higher for university graduates. The ratio of immigrants to natives among university graduates rises from 0.147 to 0.258 . Among those with less than university education this ratio rises from 0.077 to 0.088 over the same period, with almost all of the increase concentrated in recent years.

Changes in the level of educational attainment among native-born workers are given in the second panel of Table 1. There has been a secular increase in the education level of nativeborn workers. From 1975 to 2005 the ratio of graduates to non graduates in the native-born working age population rose from 0.059 to 0.231 . Even more spectacular is the increase in this ratio among immigrants - from 0.111 to 0.675 over the same period. So by the end of the sample period there were approximately two university graduates to every three non-graduates in the immigrant population.

The third panel gives the evolution of the aggregate native-immigrant wage differential, based on the estimated coefficient on a native-born dummy from a regression of male log gross weekly wages (conditional on a quadratic term in age and a dummy variable for London). This positive differential tends to fall up to the end of the 1990s - indicating a fall in the immigrant wage penalty over time. For university graduates, this differential tends to fall to the end of the 1990s and then rises again. By 2005 this differential was around $4 \log$ points higher than in 1975 $(16.1 \%$ versus $11.9 \%)$. In contrast, the native wage premium appears to have fallen steadily among secondary educated workers, with some slowdown but no sign of reversal in later years.

The final panel of Table 1 provides estimates of the return to university education for both immigrants and native-born (again conditional on a quadratic term in age and a London dummy).

\footnotetext{
${ }^{6}$ The data in Table 1 differ slightly from those in Figure 1, as the former takes averages across five contiguous years to compute averages, as described in the appendix.
} 
The overall rise in returns to education in Britain since the 1970s is well documented (see for example Machin, 2003). Perhaps less well documented are the differences in the trends and levels of returns between native-born and immigrants. While the return to university education was higher for immigrants than for natives at the beginning of the period, the graduate premium appears to have risen more among natives than among immigrants over time, so that by the end of the period the return to university education is higher among natives.

In sum, immigrant workers to the UK experienced, on average, an improvement in their labor market returns until around 2000. This, however, masks a degree of heterogeneity across groups. The return to university education among immigrants, despite being higher than for natives at the beginning of the period, grew at a much lower rate. This happened while the share of university graduates was growing more among immigrants. One possible interpretation is that immigrants - and in particular university educated immigrants - disproportionately bore the cost of increased immigration in terms of lower wages. This suggests that immigrants and natives are far from being perfect substitutes in production, a hypothesis that we explore in greater detail below.

Table 2 documents the changes in the skill mix of immigrants across the cells used in the subsequent analysis. The table contains information on the ratio of immigrants to native-born in each age-year cell for the two education groups. For example, the top left cell represents those aged 26-30 in 1975. Similarly, the second and third rows of column (1) refer respectively to individuals born 5 and 10 years later. Subsequent birth cohorts can be followed by reading across the diagonals of the table. ${ }^{7}$ For graduates, the immigrant to native ratio varies between approximately $10 \%$ and $30 \%$, with an average value of about $20 \%$. For any given age group, the share of immigrant to native-born graduates tends to rise over time. For the secondary school group, the immigrant to native ratio is closer to $10 \%$ and rises less over time. In particular for the

\footnotetext{
${ }^{7}$ Comparing the same cohort of immigrants across time is always subject to any bias caused by any selective returnmigration over time not captured by observables in our data. See Dustmann and Weiss (2007) for estimates of the extent of return migration in the UK.
} 
1960s birth cohort - highlighted in the Table - there appears to have been a slowdown in the rate of immigration of secondary-level workers.

The bottom third of the table reports the relative immigrant-native share by education. A value of one implies that immigrants are equally represented among university and secondary graduates. All these ratios are above one, confirming that immigrants to the UK are on average more educated. The relative immigrant skill ratios increase among younger cohorts. In particular, the 1960s birth cohort has the largest share of immigrants in the graduate group relative to the secondary group, though this ratio falls back somewhat over time. This is also evident in Table 1 which shows a rise in the ratio of immigrants to natives among the secondary group in the five years after the year 2000 .

Information on the estimated returns to education by immigrant status and the nativeimmigrant wage premia for each age-time cell, along with their standard errors, are reported in Tables 3 and 4 respectively. These estimates are somewhat less precise because they come from the smaller sample sizes of the GHS. However, the relative wage is the dependent variable, so any measurement error will not lead to an attenuation bias and observations with higher standard errors are given less weight in the regressions, as explained below. Reading down any column in Table 3, it can be seen that the relative returns to a university degree grew from the late 1970s onward. The baby boom cohort of the 1960s experienced a large rise in returns to education, a fact already noted by Card and Lemieux (2001) which they attribute to a slowdown in university graduation rates. Reading across the rows, it is also apparent that the age profile of the university wage premium has become much flatter over time, while also shifting up, so there is now a higher premium to all graduates of whatever age. The results for immigrants are similar but much less precisely estimated. In particular, it is evident that the rise in returns to university for the 1960s' birth cohort of immigrants is much less pronounced than for natives, especially at younger ages. Again this suggests that the acceleration in the ratio of university to secondary graduates among immigrants that occurred with the arrival of the 1960s' birth cohort potentially reduced 
immigrants' returns to university education compared to natives. This happened at a time when the slowdown in the relative supply of university workers among natives led to an unprecedented rise in their returns to education. This is also evident in Table 4 which shows a substantially higher native to immigrant wage differential for the 1960s cohort, especially among university graduates, while the opposite happens for the secondary school group of workers.

In sum, Table 2, 3 and 4 show evidence of a clear convergence in wages of immigrants and natives in the UK. This convergence came to a halt when immigration rose, especially among the most skilled. This corresponded to a large relative influx of university immigrants born in the 1960s, in part made possible by the free mobility of labor across the European Union. In the face of rising unemployment and stagnating returns to education in most of mainland Europe and rising returns to education in the UK, the early 1990s saw an increased inflow of such skilled immigrants. At the same time, rising returns to education and the deterioration of the labor market in the UK during the early 1990s recession led to a fall in the inflow of less skilled immigrants. It was not until the late 1990s that less skilled immigration bounced back.

\section{THEORETICAL FRAMEWORK}

In this section we present a stylized model of labor demand disaggregated by skill and age that allows us to estimate the impact of changes in the supply of educated labor across subsequent cohorts on the wage structure. The model is similar to Card and Lemieux's (2001) model of changes in the returns to education and the 'structural' model in Borjas (2003). However we extend Card and Lemieux's model directly, similar to Ottaviano and Peri (2010) for the US, and treat immigrant and native workers as different production inputs within each age/education cell and then estimate the elasticity of substitution between the two. 
We assume that the production function is nested CES. Firms produce output using a combination of skilled and unskilled labor according to: ${ }^{8}$

$$
Y_{t}=A_{t}\left[\theta_{t} L_{1 t}^{\rho}+L_{2 t}^{\rho}\right]^{\frac{1}{\rho}}
$$

where 1 is skilled labor, 2 is unskilled labor and $L_{e t}, e=1,2$ denotes the aggregate labor input for workers with skill $e$ at time $t$. $A_{t}$ is a skill-neutral technology parameter, $\theta_{t}$ is the efficiency of skilled relative to unskilled labor rise in $\theta_{t}$ represents skill-biased technical change. The elasticity of substitution between skilled and unskilled labor is $\sigma_{E}=1 /(1-\rho)$.

The production function is disaggregated by two groups. Implicitly, this assumes that within these two large groups, workers with different levels of education are perfect substitutes, although potentially with different efficiency parameters. Despite the fact that this approach follows an established tradition in labor economics (see for example Katz and Murphy, 1992; Card and Lemieux, 2001), there are good reasons to fear that this classification may be too restrictive. For this reason, in the empirical analysis below we test the robustness of our results to a finer disaggregation across education groups.

We model both skill-specific labor inputs as a CES combination of a set of (potentially) imperfect substitute age-specific labor inputs according to the following:

$$
L_{e t}=\left(\sum_{a} \alpha_{e a} L_{e a t}^{\eta}\right)^{(1 / \eta)}, \quad e=1,2
$$

where $a$ denotes age group $(a=1,2, A)$ and the elasticity of substitution between different age groups, $\sigma_{A}=1 /(1-\eta)$, is a parameter to be estimated and assumed to be skill invariant. The $\alpha_{e a}$ are measures of the relative efficiency of different age inputs for each education group. We follow Card and Lemieux in assuming no age-biased technical progress, so the $\alpha_{e a}$ do not vary over

\footnotetext{
${ }^{8}$ This can be thought of either as a long-run production function in which capital is endogenous or as a short-run production function in which $\mathrm{Y}$ is a composite labor input. As we only estimate models for relative wages, the discussion is not affected by the interpretation. However in the simulations in the final part of the paper, we assume that (1) is a production function. This is, of course, also not the only nesting possibility, since the top level of aggregation could be any one of age, education or age and lead to a different structural form. See Ottaviano and Peri (2010) for more discussion on this.
} 
time. Any time effects are therefore subsumed in $\left(A_{t}, \theta_{t}\right)$ at the top level of aggregation. Furthermore, we impose the normalization that $\alpha_{e l}=1$. The normalization is innocuous and can be thought of as defining the units of measurement of $L_{e t}$.

Extending Card and Lemieux's model, we next assume that each age-education specific labor input is a CES combination of native born and immigrant workers:

$$
L_{\text {eat }}=\left(N_{\text {eat }}^{\delta}+\beta_{\text {eat }} M_{\text {eat }}^{\delta}\right)^{(1 / \delta)}
$$

where $N$ is native-born, $M$ is immigrant and $\beta$ is the native-immigrant relative efficiency parameter. The coefficient on $N$ in (3) is again restricted to be equal to one without loss of generality. Equation (3) allows the relative efficiency parameters on the native and immigrant workers, $\beta_{\text {eat }}$, to vary by skill, age and time. This implies that wages of native-born relative to immigrants can vary over time even at fixed levels of demand and supply. This can be because of changes in discrimination, changes in the "quality" of the immigrant stock caused by either between or within-country of origin changes across cohorts, selective immigration or outmigration over the life cycle, as well as changing costs of assimilation.

From (3), the elasticity of substitution between immigrant and native workers is given by $\sigma_{I}=1 /(1-\delta)$. If $\delta \neq 1$, then immigrants and natives are not perfect substitutes. In this case immigration, or anything that changes the relative supply of these two groups, will change the native-immigrant wage differential.

Although for simplicity the model assumes that the elasticity of substitution between immigrant and native-born workers is the same for all age or education groups, there is no theoretical reason why this should be the case. In the empirical section below we also present specifications where we allow this parameter to vary across age and education groups.

By equating native-born and immigrant wages to the appropriate marginal products of labor, using (1) to (3) we can derive an expression for the wages of natives and immigrants in each education-age-time cell: 
$\ln W_{e a t}^{s}=\ln A_{t}+\frac{1}{\sigma_{E}} \ln Y_{t}+\ln \theta_{e t}+\ln \alpha_{e a}+\ln \beta_{e a t}^{s}+\left(\frac{1}{\sigma_{A}}-\frac{1}{\sigma_{E}}\right) \ln L_{e t}+\left(\frac{1}{\sigma_{I}}-\frac{1}{\sigma_{A}}\right) \ln L_{e a t}-\frac{1}{\sigma_{I}} \ln S_{e a t}$

where $S=N, M$ is immigrant status, (Natives $(N)$ or immigrants $(M)), \beta_{\text {eat }}^{N}=1, \beta_{\text {eat }}^{M}=\beta_{\text {eat }}, \theta_{1 t}=\theta_{\mathrm{t}}$ and $\theta_{2 t}=1$. From (4) we derive the native-immigrant wage differential in each cell:

$$
\ln \left(\frac{W_{e a t}^{N}}{W_{e a t}^{M}}\right)=-\ln \beta_{e a t}-\frac{1}{\sigma_{I}} \ln \left(\frac{N_{e a t}}{M_{e a t}}\right)
$$

Equation (5) shows that - net of changes in productivity proxied by the $\beta_{\text {eat }}$ terms - wages of native born relative to immigrant workers in each age-education cell depend inversely on their relative supply. Equation (5) is the main equation of interest in this paper. This says that if immigrants and natives are perfect substitutes - as often claimed - one should find no effect of changes in the relative employment of natives to immigrants on their relative wages (in which case $1 / \sigma_{I}$ will be zero)

One can also use (4) to obtain the relative returns to education by age, time and immigrant status. The relative wage of skilled to unskilled for age group $a$ at time $t$ in group $S$ is given by:

$$
\ln \frac{W_{1 a t}^{S}}{W_{2 a t}^{S}}=\ln \theta_{t}+\ln \left(\frac{\alpha_{1 a}}{\alpha_{2 a}}\right)+\ln \left(\frac{\beta_{1 a t}^{S}}{\beta_{2 a t}^{S}}\right)-\frac{1}{\sigma_{E}} \ln \frac{L_{1 t}}{L_{2 t}}-\frac{1}{\sigma_{A}}\left(\ln \frac{L_{1 a t}}{L_{2 a t}}-\ln \frac{L_{1 t}}{L_{2 t}}\right)-\frac{1}{\sigma_{I}}\left(\ln \frac{S_{1 a t}}{S_{2 a t}}-\ln \frac{L_{1 a t}}{L_{2 a t}}\right)
$$

This shows that returns to education by age for each nativity group $S$ depend on some measure of changes in demand for skills $\left[\ln \theta_{t}+\ln \left(\alpha_{1 a} / \alpha_{2 a}\right)+\ln \left(\beta_{1 a t}^{S} / \beta_{2 a t}^{S}\right)\right]$, the aggregate relative supply by education $\ln \left(L_{1 t} / L_{2 t}\right)$, the deviation in the supply of each age group relative to the overall supply $\left[\ln \left(L_{\text {lat }} / L_{2 a t}\right)-\ln \left(L_{1 t} / L_{2 t}\right)\right]$ and the contribution of the nativity group to the supply of each ageeducation group $\left[\ln \left(S_{\text {lat }} / S_{2 a t}\right)-\ln \left(L_{\text {lat }} / L_{2 a t}\right)\right] .{ }^{9}$ Equations (5) and (6) are the basis for the empirical work that follows.

\footnotetext{
${ }^{9}$ If $\sigma_{\mathrm{I}} \rightarrow \infty$, then equation (6) is the same as that estimated by Card and Lemieux (2001).
} 


\section{ESTIMATION AND IDENTIFICATION}

The problem with estimating (6) directly is that in order to estimate $\sigma_{A}$, an estimate of $L_{e a t}$ is needed. Equation (3) shows that this in turn requires estimates of the $\beta_{\text {eat }}$ and $\sigma_{I}$. Similarly in order to obtain an estimate of $\sigma_{E}$ we need an estimate of $L_{e t}$ and equation (2) tells us that we need estimates of the $\alpha_{e \mathrm{a}}$ and $\sigma_{A}$. We therefore proceed iteratively.

\subsection{Step 1. Estimating $\sigma_{\mathrm{I}}$ and $\beta_{\text {ea } t}$}

Using (5) we constrain $\ln \left(\beta_{\text {eat }}\right)$ to vary additively by skill, time and age for both the native-born and immigrants, although in the empirical part we also apply less restrictive specifications. It follows that:

$$
-\ln \beta_{\text {eat }}=f_{e}+f_{a}+f_{t}
$$

Given this we can obtain an estimate of $\sigma_{I}$ from (5) based on estimation of the following:

$$
\ln \left(\frac{W_{e a t}^{N}}{W_{e a t}^{M}}\right)=f_{e}+f_{a}+f_{t}-\frac{1}{\sigma_{I}} \ln \left(\frac{N_{e a t}}{M_{\text {eat }}}\right)
$$

We regress the log relative wage of native to immigrant workers for each age-education-time cell on the relative supply for each cell alongside skill, age and time dummies. The coefficient on the cell-specific relative supply of migrants gives an estimate of the elasticity of substitution between immigrants and natives. The coefficients on the education, age and time dummies provide estimates of each $\beta_{\text {eat }}$ using (7). We then use these estimates to compute $L_{\text {eat }}$ using (3).

\subsection{Step 2: Estimating $\sigma_{A}$ and $\alpha_{e a}$}

Given these estimates we use (6) to estimate the relative returns to education separately for the native born and for immigrants. Given our assumptions, the relative returns are given by:

$$
\ln \frac{W_{1 a t}^{S}}{W_{2 a t}^{S}}=d_{a}+d_{t}+d_{S}-\frac{1}{\sigma_{A}}\left(\ln \frac{L_{1 a t}}{L_{2 a t}}\right)-\frac{1}{\sigma_{I}}\left(\ln \frac{S_{1 a t}}{S_{2 a t}}-\ln \frac{L_{1 a t}}{L_{2 a t}}\right)
$$


where the time dummies, $d_{t}$, capture the time-variant part of (6), the age dummies, $d_{a}$, capture the relative age-effects on productivity, i.e. $\ln \left(\alpha_{1 a} / \alpha_{2 a}\right)$ and the immigrant dummy variable, $d_{S}$, captures the effect of $\ln \left(\beta_{\text {lat }}^{S} \beta_{2 a t}^{S}\right)$. The coefficient on the cell-specific relative supply of graduates to secondary workers gives an estimate of the elasticity of substitution across age groups, $\sigma_{A}$. Estimation of (9) also provides a new estimate of $\sigma_{I}$ and hence an implicit test of the specification of the model. One can then recover estimates of the $\ln \left(\alpha_{e a}\right)$ based on (4) since:

$$
\ln W_{e a t}^{s}=d_{e t}+d_{e a}-\frac{1}{\sigma_{A}} \ln L_{e a t}-\frac{1}{\sigma_{I}}\left[\ln S_{\text {eat }}-\ln L_{e a t}+\sigma_{I} \ln \beta_{\text {eat }}\right]
$$

The coefficients on the estimated $d_{e a}$ dummies enable us to recover the $\alpha$ parameters and so compute $L_{e t}$ using (2).

\subsection{Step 3: Estimating $\sigma_{E}$ and $\theta_{t}$}

We then re-run equation (6) using the computed labor supply terms, assuming, as in Card and Lemieux (2001) that the skill biased technical change term, $\ln \left(\theta_{t}\right)$, varies linearly with time i.e. we estimate:

$$
\ln \left(\frac{W_{1 a t}^{s}}{W_{2 a t}^{s}}\right)=\kappa_{0}+\kappa_{1} t+d_{a}+d_{s}-\frac{1}{\sigma_{E}} \ln \left(\frac{L_{1 t}}{L_{2 t}}\right)-\frac{1}{\sigma_{A}}\left[\ln \left(\frac{L_{1 a t}}{L_{2 a t}}\right)-\ln \left(\frac{L_{1 t}}{L_{2 t}}\right)\right]-\frac{1}{\sigma_{I}}\left[\ln \left(\frac{S_{1 a t}}{L_{1 a t}}\right)-\ln \left(\frac{S_{2 a t}}{L_{2 a t}}\right)\right](
$$

Equation (11) provides an estimate of the elasticity of substitution between the two skills groups $\left(\sigma_{E}\right)$, skilled biased technological change $\left(\kappa_{1}\right)$ as well as new estimates of the $\sigma_{I}$ and $\sigma_{A}$.

\section{ESTIMATES OF THE ELASTICITY OF SUBSTITUTION BETWEEN IMMIGRANTS} AND NATIVES

We now use the data in Tables 2 to 4 to estimate the model. The first step is to estimate equation (8), from which we can recover an estimate of the elasticity of substitution between immigrants and natives. This is the key parameter in the paper so we present a number of different specifications to examine the sensitivity of the estimates. 
Row 1 provides the baseline estimate of step 1 of the model. Since the dependent variable, the native-immigrant wage differential, is based on individual wages within each cell, we use the reciprocal of the variance on these estimated returns as weights and run minimum distance weighted least squares regressions, so that more precisely estimated wage differentials receive higher weight. ${ }^{10}$

The model controls for additive age, time and education dummies. The reported coefficient gives the estimate of the coefficient on the supply of natives relative to immigrants in the relative wage equation, the negative of the reciprocal of the elasticity of substitution between immigrants and natives $\left(-1 / \sigma_{I}\right)$. If there were perfect substitution the coefficient on relative supply would be zero. However, the estimates suggest that the overall native-immigrant wage differential is lower when immigration is lower. The estimated coefficient is -0.128 and significant at conventional levels, implying an elasticity of substitution between immigrants and natives of around $7.8(=1 / 0.128)$. This coefficient is about one third higher (and the implied elasticity of substation three times lower) than those recently found by Card (2009) and Ottaviano and Peri (2010) for the US. We return to possible explanations for these differences in the conclusions to the paper.

To show that these results are not driven by outliers, in Figure 2 we plot the log nativeimmigrant wage for each age, time and education cell against the log native-immigrant ratio in that cell. The values are residuals from regressions of the relevant variables on additive time, age and education dummies. Each circle represents an observation, with larger circles implying greater weight. The solid line in the figure is the estimated regression line. One can see clearly that the results are not driven by outliers and that a similar relationship between wages and relative supply appears to hold for both those with secondary and those with university education.

How plausible is our finding that immigrants and natives within age-education cells are imperfect substitutes? One way to address this is to compare the distribution of jobs done by

\footnotetext{
${ }^{10}$ We use analytical weights in Stata.
} 
immigrants and natives, an approach also taken, for example, by Borjas (2003). The top panel of Table 6 presents Duncan indices of segregation for immigrants and natives across 3-digit occupations in the LFS for the period 2003-2006. For all age-education cells the segregation indices are in the region $0.20-0.34$ implying that between $20 \%$ and $34 \%$ of immigrants (and natives) would have to change jobs to equalize the occupational distribution of employment. The bottom panel outlines the share of natives and immigrants in each 1-digit occupation group again split by education. For both secondary and, interestingly, for tertiary workers there is a much larger tail of immigrant workers in the elementary occupations compared to natives. Some $11 \%$ of immigrant university graduates are working in elementary occupations. Together, the data suggest that the amount of segregation is sizeable, so that it is not implausible to think of natives and immigrants as being imperfect substitutes within age-education cells.

In the rest of this section we present a battery of robustness checks regarding the estimate of the elasticity of substitution between immigrants and natives.

\subsection{Recent versus Earlier Immigrants}

Although we pool immigrants into a single group, this does comprise a heterogeneous set of individuals, including those who came to the UK as children or those who acquired their secondary education in the UK. One might expect these workers to be closer substitutes for natives than other immigrants. In rows 2 and 3 of Table 5 we report separate estimates of the elasticity of substitution among recent immigrants (those who arrived in the last five years) and longer-term immigrants (those who arrived more than five years ago). However, we use all immigrants (whether recent or longer term) to compute the supply for each cell - exactly as in the baseline specification. This is because information on time since immigration is not available in the LFS for the entire sample period.

For recent immigrants, row 2 reports an estimated coefficient on the supply term of -0.216, implying a lower degree of substitution (of around 5) between natives and recent 
immigrants than for all immigrants. This suggests that recent immigrants bear more of the costs of changes in the stock of immigrants. This is confirmed in row 3 where we restrict the definition of immigrants to those who have been in the country for more than five years. We find that these workers are less sensitive to immigration inflows, with an estimated coefficient on the supply term of -0.099 , i.e. around $20 \%$ smaller than the baseline estimate, although the standard errors do not allow us to reject the hypothesis that the coefficients are the same for recent and longerterm migrants.

The last column of Table 5 gives the p-value for a test for the equality of each coefficient relative to the baseline estimate in row 1 . The hypothesis that the estimates from the two models are the same as the baseline estimate cannot be rejected.

\subsection{Saturated Model}

It is possible that there are particular age-education-year observations which tend to be systematically on the right or left of Figure 2 . We therefore re-estimate the model with less restrictive assumptions on the education-age-year dummies. Row 4 of Table 5 gives an estimate of equation (8) where we include controls for all pair-wise interactions between the age, education and time dummies, (similar to Borjas et al., 2008). This model is very saturated and identification of the elasticity of substitution is based on the full interaction of age, time and education. Even in this model, the negative effect of relative supply remains. The point estimate is -0.204 , significant at the $10 \%$ level. We cannot reject the hypothesis that the estimate from the saturated model is the same as the baseline estimate.

\subsection{Heterogeneous Effects across Education Groups}

Although the model assumes that the elasticity of substitution between natives and immigrants is the same across education groups, there is no reason why this should be the case. In row 5 of Table 5 we interact the supply term with the two education dummies. Although the point 
estimates differ across education groups - with secondary educated natives being more responsive to competition from similarly educated immigrants relative to university graduates - the hypothesis that the two coefficients are the same and that they are both equal to the baseline estimate cannot be rejected at usual significance levels. ${ }^{11}$

In row 6 we report estimates of a model where the supply term is interacted with dummies for three age groups: young workers (ages 26-35), mid-age workers (age 36-50) and older workers (age 51-60). The estimated parameter falls in absolute value with age and is only statistically significant for younger workers. This implies that elasticity of substitution between natives and workers increases with age. Although we cannot rule out that this result is due to any selective propensity to return to the home country among immigrants that are less substitutable with natives or even due to permanent cohort effects (i.e. migrants from more recent cohorts are less substitutable with natives), one plausible interpretation is that the degree of substitution between natives and migrants disappears as migrants assimilate in the host country.

\subsection{Changing the Definition of Cells}

Our results might be sensitive to the cell definition. In row 7 we present estimates based on cells disaggregated instead by time, education and potential experience (age minus age left full-time education) rather than age. The result is essentially unchanged, with a coefficient of $-0.126 .^{12}$

We also changed the grouping of individuals into different age and time cells aggregates. In most of the analysis we use five-year five-year-age cells. We repeat the analysis using threeyear, three-year-age cells. The number of cells now increases from 98 to 220 . The estimated coefficient reported in row 8 of Table 5 is -0.082 . This is significant only at a $10 \%$ level and again not statistically distinguishable from the baseline estimate.

\footnotetext{
11 Dustmann, Frattini and Preston (2008) find that immigration appears to depress the UK native-born wage distribution below the $20^{\text {th }}$ percentile and raises it toward the top of the distribution. This is consistent with the idea of different levels of imperfect substitution across the skill distribution, of which one possible explanation may be occupational downgrading by skilled immigrants on arrival.

${ }^{12}$ We also interacted the supply term with dummies for different levels of experience rather than different age groups (as in row 6). Results (not reported) are remarkably similar to those in row 6.
} 
So far we have grouped individuals into two education groups: "secondary equivalents" and "university graduates". This is the same partition used by Card and Lemieux (2001). There are, however, good reasons to test the robustness of our results to a more detailed education partition, including the fact that such a distinction appears to be relevant for the US. ${ }^{13}$

Based on the "age left full-time education" variable to define education, it is possible to present a plausible three-group partition. We therefore split the bottom group into those with precisely secondary education (left full-time education at ages 16-20) and those with less than secondary qualification (left full-time education before age 16). The results, in row 9, are similar to the baseline estimate: we still find imperfect substitution between natives and immigrants within education groups. The point estimate falls from -0.128 to -0.107 and is again statistically significant, implying that the finite elasticity of substitution between immigrants and natives is not a statistical artifact of our binary partition into two groups.

We also test whether the age cutoff points used to group education affect the estimates. The minimum school leaving age in the UK has been 16 since 1974, so the primary school group includes largely older workers (who completed school before 1974) and immigrants. To test how sensitive our results are to this classification, in row 10 of Table 5 we assign workers who left full-time education at age 16 to the primary (as opposed to the secondary) group. Similarly, in row 11 we assign workers who left full-time education at age 20 to the university group (as opposed to the secondary group). Once again this makes little difference to our results.

\subsection{Ignoring Efficiency Units}

\footnotetext{
${ }^{13}$ Recent immigration to the US was dominated by high school drop outs and there are virtually no native US workers in this category. Card (2009) and Ottaviano and Peri (2008) argue that because these two groups are close to perfect substitutes, the effect of immigration among unskilled got diluted among a larger group of natives, making its overall impact small. Borjas (2003) instead uses a partition of the labor force into four education groups, applying the same elasticity of substitution across all four groups. There is some disagreement as to whether this difference in the education partition is the reason for the different results. Comparing early to later results from Ottaviano and Peri (2006 and 2008, respectively) - at least for some specifications - using a fourfold as opposed to a binary education classification makes little difference to the estimated coefficients.
} 
In the baseline estimates in Table 5 the supply of secondary education equivalents is computed as the weighted sum of those with exactly secondary education (left full-time education between ages 16-20) and those with less than secondary education (left full-time education before age 16), where the weights are given by the relative wages of secondary school dropouts relative to those with completed secondary education by age, time and immigrant status. These weights (contrary to the wages on the left hand side) are time invariant, since they are averages by cell over time.

One might still be concerned about the potential division bias induced by wages being on both the right and the left hand sides of equation (8). In practice, this should not be much of a concern, as our specifications control for age and education dummies (and sometimes also for the interactions of the two) and the weights do not vary with time. To cut through this problem we present results (in row 12 of Table 5), where the supply of "secondary equivalent" workers is computed as the unweighted sum of workers with precisely secondary education and those with incomplete schooling, so using no efficiency weights. The results are again remarkably similar to those from the baseline regression.

\subsection{Changing Regression Weights}

The baseline regression weights the data by the inverse of the estimated variance of the nativemigrant wage differential for each age-education-time cell. In rows 13 and 14 we report respectively unweighted regressions and regressions using the number of individuals in each cell (immigrants plus natives) as weights. There is no significant difference in the estimated results.

\subsection{Including Marginal Workers}

Recent evidence for the US suggests that the estimated coefficient on relative supply in an equation similar to (8) depends crucially on the sample make-up and in particular on the inclusion in the wage sample of workers with poor attachment to the labor market, (students and part-time 
workers). ${ }^{14}$ This is not a problem for our estimates, since we only include full-time workers not in education. To check whether our estimates are sensitive to the inclusion of other workers, row 15 gives the results from a specification including part-time workers, giving each worker a weight equal to their weekly hours of work to compute average wages by cell. The estimate is approximately $20 \%$ larger than the baseline estimate $(-0.152)$ but again not statistically different from it.

\subsection{Hours Instead of Population}

Our baseline estimates use population as a measure of labor supply because we think this is a more exogenous source of variation in supply than employment or hours often used in other studies. One can think of our estimates as a "reduced-form", but, there is a danger that our estimates reflect not just labor demand but also labor supply elasticities. This is true to the extent that aggregate labor supply is upward sloping, but perhaps less of a concern for prime age males used in this study.

In order to present results comparable to those produced elsewhere and in order to check for the potential effect of changes in labor supply on hours of work, we repeat the exercise using first hours of work as alternative measures of supply in (8) and then instrument hours of work with the population in each cell. Both the OLS and the IV estimates - in rows 16 and 17 respectively - are remarkably similar to the baseline estimate. This also suggests no appreciable employment effect of immigration. Consistent with this, a regression of hours on population (the first stage estimate of the IV procedure), with the same controls as those in row 1 of Table 5, leads to an estimated coefficient of 0.992 (se. 0.079). Estimates using employment are similar and are not reported here. These results are consistent with the idea that the adjustment to immigration in the UK is - if anything - on the wage side.

\footnotetext{
${ }^{14}$ Borjas et al. (2008) suggest that the early results by Ottaviano and Peri (2006) depend partly on the inclusion of marginal workers (students and part time-workers), whose wage is a poor measure of the "marginal price of labor".
} 


\subsection{Including Women in the Sample}

So far we have restricted the analysis to men's wages using male labor supply to identify the relevant elasticities. In the remaining rows of Table 5 we investigate what happens when we include women in the analysis.

Women's labor force participation and employment are more likely to be endogenous to wages, and the parameters of the labor supply equation are likely to have changed considerably over the period of analysis (see also Borjas et al., 2008). Second, as many women typically withdraw temporarily from the labor market for child bearing and child raising, the correspondence between age and experience might differ between native and immigrant women, those with different educational levels and over time, implying that it is difficult to make any sensible inference based on these grouped data.

With these caveats in mind, we present estimates of equation (8) for women only in row 18 of Table 5. The estimated coefficient is -0.066 (s.e. 0.062 ). While we cannot reject the hypothesis that the parameter is zero (i.e. an infinitely high elasticity of substitution between immigrant women and native women), we cannot equally reject that this is the same as the coefficient for men (-0.128). So the results are slightly inconclusive. This is not surprising as in the GHS there are fewer female than male wage earners per cell: around 37 (versus 57 for men), so the estimates for women are less precise.

We have also estimated the model pooling cells for men and women (so overall we have 196 cells: 98 for men and 98 for women). We use the same specification as in row 1 and additionally interact all the controls with a gender dummy, constraining the elasticity of substitution between immigrant men and immigrant women to be the same. The results in row 19 are extremely similar to the results for men only (point estimate -0.109 , s.e. 0.036 ).

As a last check we assume that men and women are perfect substitutes. In this case, both male and female native to immigrant wage differentials only depend on the supply of natives (men plus women) relative to immigrants (men plus women). Again, the estimated coefficient on 
the relative supply of natives versus immigrants, row 20 , remains essentially unchanged $(-0.115$, s.e. 0.043 ). These estimates show that the results also hold if we include women in the sample, although the results for women only are more ambiguous.

\subsection{Estimates of the Other Parameters of the Model}

We now proceed to estimate the other parameters of the model in Sections 3 and 4. This allows us to estimate the overall impact of immigration on the wage structure in the next section and to check how this enriched model affects the conclusions of Card and Lemieux (2001).

We present these estimates in Table 7 . In column 1 we report again our baseline specification for step 1, as in the first row of Table 5. The second column reports estimates of step 2, i.e. a new estimate of this coefficient together with an estimate of the coefficient on the effect of changes in the relative supply of skills by age and time on the returns to university education based on equation (9). ${ }^{15}$ The estimated coefficient on native-immigrant relative supply is very similar to the one in column 1 , (falling from -0.128 to -0.144 ) and the resulting elasticity between immigrants and native-born moves from 7.8 to around 7 . The estimated coefficient on age-specific relative labor supply, $-1 / \sigma_{A}$, is -0.196 and statistically significant. This implies an elasticity of substitution across workers of different ages $\left(\sigma_{A}\right)$ of around 5 , very similar to the estimate of around 4.5 found for Britain by Card and Lemieux (2001). In column 3 we report new estimates of the effects of the share of natives to immigrants and the relative supply of university workers by age alongside the estimate of the overall effect of the relative supply of university workers based on equation (11). The estimated coefficient on the linear time trend, which can be thought of as a measure of the rate of skill-biased technical change, is 0.016 , so that the university to secondary wage gap would have grown by around $1.6 \%$ a year over the sample period in the absence of relative supply changes.

\footnotetext{
${ }^{15}$ We follow Card and Lemieux (2001) in their computation of standard errors, although some caution is needed here as the standard errors in columns 2 and 3 might be biased due to the use of estimated regressors as covariates. In principle bootstrapped standard errors could be computed (see Fitzenberger and Kohn, 2006).
} 
The data imply an estimated coefficient on the relative supply of university to secondary workers of about -0.203 , implying an elasticity of substitution between university and secondary workers, $\sigma_{E}$, of around 5. This is about twice the estimate of 2.5 found by Card and Lemieux. Our different sample periods, sample sizes, differences in the data used to estimate labor supply, different weights given to immigrant and native workers and different definitions of education are all likely to underlie these differences. The estimate of the elasticity of substitution between native born and immigrants again remains virtually unchanged.

\section{COMPUTING THE EFFECT OF IMMIGRATION ON WAGES}

We now use the estimates to simulate the effect of changes in the stock and skill mix of immigrants on the wages of different groups. In doing so we regard equation (1) as an actual production function rather than a composite labour input, so it is best to think of this as being a long-run analysis of a situation in which capital is endogenous and in perfectly elastic supply. We report the effects on the level of wages for natives and immigrants, skilled and unskilled. We use equation (4) to derive the different elements of the decomposition. The explicit expressions for the effect of immigration on wages are derived in the Technical Appendix. For the computation we use the estimates of the parameters $\sigma_{E}, \sigma_{I}$ and $\sigma_{A}$ from the final column of Table 7 and the actual changes in the supply of immigrants for each cell that occurred between 1975 and 2005, assuming that the level of native employment has remained constant between 1975 and 2005, so that the size of the cells of all native groups are held at their 1975 levels

Equation (4) illustrates that a rise in immigration in a specific age-education cell will first of all reduce the wages of immigrants. This is the term $-1 / \sigma_{l} \ln S_{a e t}$ and its negative sign is due to the assumption of decreasing marginal productivity of labour. This effect is reported in the first column of Table 8 . The rise in immigration that occurred over the thirty years of analysis had a sizeable effect on the wages of skilled immigrants. At fixed demand for labour, this would have implied a fall in the wages of highly educated immigrants on the order of 0.8 percentage points a 
year, implying a fall over the thirty years of analysis of more than 24 percentage points. Obviously, this is large, but one has to remember that at the same time the demand for skills (the term $\theta_{t}$ ) grew and so did the demand for immigrants (the term $\beta_{\text {eat }}$ ), whose quality, or at least whose returns relative to natives, improved. The direct effect of increased immigration among unskilled migrants is small but positive, as their overall supply fell, although as shown in Figure 1 and Table 1 - less so than among natives. By construction, changes in the supply of immigrants have no direct effect on the wages of natives as shown in rows 3 and 4 of column 1.

The second column of Table 8 reports the effect due to increased supply of labour in any given age group. This is the term $-\left(1 / \sigma_{A^{-}} 1 / \sigma_{I}\right) \ln L_{a e}$ and it is the same for immigrants and natives. First, a rise in immigration lowers the wages of all workers (natives and immigrants) in the affected age-education group relative to the average education-specific wage. This is true to the extent that different age groups are not perfect substitutes in production, otherwise this effect will get diluted among all workers in that education group, irrespective of age. This effect is counterbalanced by a rise in wages due to complementarity between natives and immigrants within age-education cells. Table 7 shows that $\sigma_{A}$ is approximately equal to $\sigma_{I}$, meaning that the degree of substitution between a immigrant and native worker with the same age and education is approximately the same as the degree of substitution between two workers in different age groups with the same education (irrespective of whether they are natives or immigrants). Hence this effect will be small, (column 2). The small magnitude of this effect is reinforced by the fact that immigrants account for a relatively small share of the population in each group. The effect is negative and marginally larger for university workers, as immigrants are more numerous in this group in the UK.

There is also therefore little additional effect of changes in the aggregate supply of each educational group. This is the term $-\left(1 / \sigma_{E^{-}} 1 / \sigma_{A}\right) l n L_{e t}$ in equation (4). Again, a rise in immigration in a certain age-education group will lower the wages of everybody in that education group, although this effect will be tempered by the substitution between workers with different levels of 
education. As above, because $\sigma_{A}$ is approximately equal to $\sigma_{E}$ this effect will be small: this is confirmed in column 3 of Table 8 .

Finally, immigrants to the UK increase total output and hence wages. This is the term $1 / \sigma_{E} \ln Y_{\mathrm{t}}$ in equation (4). This effect is again small (in the order of 0.01 percentage points a year), largely because immigrants only account for a small share of total output.

The effects on the native wage differential by education and the returns to education for the two nativity groups are reported in the bottom part of the table. The only sizeable effect of immigration to the UK over the last thirty years was on the wages of university educated immigrants. Had the demand for skills not grown over this period (by around 1.6 percentage points a year) and even more so for immigrants (in the order of 1 percentage point a year - our estimate of the trend in $\ln \beta_{a e t}$ ), the large inflow of skilled immigrants would have led to a deterioration in their wages and an ensuing fall in the immigrants' university-secondary school wage gap. The trend in the native-migrant wage differential among university workers observed in Table 2 is precisely consistent with these supply effects. Since the effect of immigration was essentially only on the wages of migrants, it is not then too surprising that researchers have failed to detect any significant effect of immigrants on native outcomes in the UK.

We have recomputed the figures in Table using a value for the elasticity of substitution equal to three times that in Table $7\left(\sigma_{I}=7 \times 3=21\right)$. This is because, estimates that have recently emerged in the literature for the elasticity of substitution between immigrants and natives in the US are in the order of 20 (Card, 2009, Ottaviano and Peri, 2010). Using this new value, we still find that the effect of increased immigration was largely concentrated among immigrants. This led to a reduction of -0.36 percentage points a year in the wages of university immigrants and less than a quarter of this among university natives. Again, there is no effect among secondary school workers, whether natives or immigrants. That the effect is larger for natives should not be surprising as the higher elasticity of substitution between immigrants and natives implies that shocks to immigrants supply get transmitted to the wages of similar (in terms of age and 
education) natives. Overall, though, even with this very high elasticity of substitution, we find that the effect of increased immigration would have been largely among university immigrants.

\section{CONCLUSIONS}

The UK has experienced a significant rise in immigration over the past thirty years, without any appreciable effect on the average wages and employment of native-born workers. This study shows that it is possible to understand how this can happen by allowing native-born workers and immigrants to be imperfect substitutes in production.

We show that the large rise in immigration experienced in Britain over the past decades does indeed appear to have changed the wage structure but not in the way often postulated. We find that, within narrowly defined age-education cells immigration, depresses the earnings of previous immigrants relative to the native-born, suggesting imperfect substitution between natives and immigrants in production. Recent immigrants are particularly sensitive to new immigrant inflows. Our results hold up against a large set of robustness checks, including the ones that some argue plague comparable estimates for the US.

The data show that the slowdown in the relative supply growth of native university workers that started with the baby boom cohort led to a rise in returns to university education among natives in that cohort but not among immigrants. Indeed, the reverse appears to have happened for immigrants. In line with the predictions of Borjas' (1987) model of immigrants' self-selection, potentially lured to Britain by the higher returns to education, university educated immigrants from the 1960 s both cohort suffered a deterioration in their relative returns due to competition from the pool of equally highly educated foreign born workers in their cohort.

When combined with Card and Lemieux's (2001) findings that the return to university education in the UK is sensitive to the relative aggregate supply of university graduates, a conclusion that we confirm even after the addition of more recent data, our finding of imperfect substitution between immigrants and natives implies that - when immigration has a different skill 
mix from the native population - this will also affect the returns to education. Because immigrants to the UK are better-educated than natives, immigration has reduced the return to university education among both immigrants and natives. However, because of the imperfect substitutability between natives and immigrants and the fact that the immigrant share is still quite low, the size of this effect is small, so it is not surprising that existing studies have failed to find a significant effect on the labor market outcomes of natives. Our conclusions suggest that the main impact of increased immigration in the $\mathrm{UK}$ is on the wages of immigrants who are already here.

Changes in relative wages need not, of course, be the only response to a change in labour supply. Lewis (2005) in particular points out that capital technique may change following a migration-induced change in the labour supply mix, so that adjustment might not manifest in wage changes. We see our explanation for little discernible impact of immigration on wages as complementary, rather than alternative, to existing explanations.

Our finding that immigrants and natives appear to be imperfect substitutes in production in the UK resembles that of Ottaviano and Peri (2010) for the US. Their estimates for the US though point to a higher degree of substitution between migrants and natives than our findings for the UK. While our robustness checks above address some of the concerns that have been the source of some discussion in the US literature, there is no obvious way to ascertain what precisely drives differences between the estimates for these two countries: different samples, different variable definitions or possibly different values in the underlying technological parameter are all potential candidates. It is worth emphasizing though that Ottaviano and Peri's estimates refer to between Census, i.e. long-run, changes in wages and employment. To the extent that any given group of migrants appear to become more substitutable with natives as time goes on, a fact that we confirm in our data, this might explain why estimates for the US point to a higher degree of substitution.

We make no claim that these results can be generalized to other countries. More data, in particular from countries that experienced skill-biased immigration inflows, are needed before 
this conclusion can be reached. Our findings also suggest a degree of heterogeneity around our central estimate, so that, for example, longer-term immigrants appear to be closer substitutes with natives than more recent immigrants, and the same holds for less skilled compared to more skilled immigrants. The factors that drive these findings still need to be uncovered. Occupational downgrading among certain groups, institutional barriers to occupational practice or even discrimination may be promising areas for future research.

\section{References}

Angrist, J. and Kugler, A. (2003) "Protective or Counter-Productive? Labour Market Institutions and the Effect of Immigration on EU Natives. " Economic Journal, 113, F302-F331.

Aydemir, A. and Borjas, G. (2006a) "A Comparative Analysis of the Labor Market Impact of International immigration: Canada, Mexico and the United States,” NBER Working Paper 12327. Aydemir, A. and Borjas, G. (2006b) “Attenuation Bias in Measuring the Wage Impact of Immigration. ” University of Harvard, mimeo.

Bell, B. (1997) "The Performance of Immigrants in the United Kingdom: Evidence from the GHS.” The Economic Journal, 107, 441 (March), 333-344.

Borjas, G. (1987) "Self-Selection and the Earnings of Immigrants." American Economic Review, 77, 4, 531-553.

Borjas, G. (1987) “Immigrants, Minorities and Labour Market Competition.”, Industrial and Labour Relations Review, 40, 3, 382-92.

Borjas, G. (1999) “The Economic Analysis of Immigration” in O. Ashenfelter and D. Card (eds.), Handbook of Labour Economics, 3, 1697-1760.

Borjas, G. (2003) "The Labour Demand Curve is Downward sloping: Re-examining the Impact of Immigration on the Labour market” Quarterly Journal of Economics, 118, 1335-1374.

Borjas G, R. Freeman and L. Katz (1996) "Searching for the Effect of Immigration on the Labour Market", American Economic Review, 86, 2, 246-251.

Borjas, G. (2009) "The Analytics of the Wage Effect of Immigration." NBER working paper, W14796, March 2009.

Borjas G., Grogger, and Hanson G. (2008) "Imperfect Substitution between Immigrants and Natives: A Reappraisal.” NBER working paper, W13887.

Card, D. (1990) “The Impact of the Mariel Boatlift on the Miami Labour Market.” Industrial and Labour Relations Review, 43, 2, 245-257.

Card, D. (2001) "Immigrant Inflows, Native Outflows, and the Local Labour Market Impacts of Higher Immigration. ” Journal of Labour Economics, 19, 1, 22-63.

Card, D. (2005) “Is the New Immigration Really So Bad?” Economic Journal, 115, F00-F323.

Card D. (2009) “Immigration and Inequality. ”American Economic Review, 99, 2, 1-21. 
Card, D. and DiNardo, J. (2000) "Do Immigrant Inflows Lead to Native Outflows?" American Economic Review, 90, 2, 360-367.

Card, D. Lemieux, T. (2001) "Can Falling Supply Explain The Rising Return To College For Younger Men? A Cohort-Based Analysis,” Quarterly Journal of Economics, 116, 2, 705-746.

Chiswick B. Chiswick C. and Miller P. (1985) "Are Immigrants and Natives Perfect Substitutes in Production?” International immigration Review, 19, 4, 674-685.

Dustmann, C. and Fabbri F. (2003) "Language Proficiency and Labour Market Performance of Immigrants in the UK. ”Economic Journal, 113, 695-717.

Dustmann, C. and Fabbri F. (2005) "Immigrants in the British Labour Market .", Fiscal Studies, 26, 4, 423-470, 2005.

Dustmann, C. Fabbri, F. and Preston I. (2005) "The Impact of Immigration on the UK Labour Market.” Economic Journal, 115, pp F324-F341.

Dustmann, C. Glitz A. and Frattini T. (2008) “The Labour Market Impact of Immigration.” CREAM discussion paper, 11/08.

Dustmann, C. Frattini T. and Preston I. (2008) “The Effect of Immigration Along the Distribution of Wages. " CREAM discussion paper, 03/08.

Dustmann, C. and Weiss Y. (2007) "Return Migration: Theory and Empirical Evidence form the UK." British Journal of Industrial Relations, 445, 2, 236-256.

Fitzenberger B. and K. Kohn (2006) "Skill Wage Premia, Employment, and Cohort Effects: Are Workers in Germany All of the Same Type?.”, IZA Discussion Papers 2185.

Grossman, J. (1982) “The Sustainability of Natives and Immigrants in Production. ”, Review of Economics and Statistics, 64, 4, 596-603.

Jaeger, D. (2007) "Skill Differences and the Effect of Immigrants on the Wages of Natives." unpublished, William and Mary College.

Katz, L. and K. Murphy (1992) "Changes in Relative Wages, 1963 1987: Supply and Demand Factors. " Quarterly Journal of Economics, 107, 1, 35-78.

Lalonde, R. and Topel, R. (1991) “Labour Market Adjustments to Increased Immigration.”, in Immigration, Trade and Labour, (eds.) J. Abowd and R. Freeman, University of Chicago Press.

Lewis, E. (2005) "Immigration, Skill Mix and the Choice of Technique.", Federal Reserve Bank of Philadelphia 05-8

Manacorda M., Manning A. and Wadsworth J. (2006) “The Impact of Immigration on the Structure of Male Wages: Theory and Evidence from Britain." CEP Discussion Papers, CEPDP0754, October 2006.

Machin, S. (2003) “Wage Inequality Since 1975." in R. Dickens, P. Gregg and J. Wadsworth (eds.) The Labour Market Under New Labour: The State of Working Britain, Palgrave-Macmillan Press, London.

OECD, (2004) Trends in International immigration, 2004, OECD, Paris

OECD, (2006) International immigration Outlook, 2006, OECD, Paris

Ottaviano, G. and Peri, G. (2010) "Rethinking the Effect of Immigration on Wages”, Journal of the European Economic Association, this issue.

Saleheen, J. and Shadforth, C. (2006) "The economic characteristics of immigrants and their impact on supply.” Bank of England Quarterly Bulletin, Q4, 374-385. 
Schmitt, J. and Wadsworth, J. (2007) "Changing Patterns In The Relative Economic Performance of Immigrants to Great Britain and the United States, 1980-2000." British Journal of Industrial Relations, 55, 4, 659-686. 


\section{DATA APPENDIX}

\section{Definition of Education.}

When analysing UK education related issues, it is standard practice to define education by the highest level of qualifications obtained. However, this is not possible when considering immigrants as, in both the GHS and LFS, a large share of foreign qualifications are placed in the 'other qualifications' category. For a native-born worker a response that their highest qualification is in the 'other' category almost certainly means a low level of education, as all the major UK educational qualifications are covered by the alternative categories. There are however good reasons to believe that many of the immigrants placed in the 'other' category have rather high levels of qualifications, (see the discussion paper version of this paper and Saleheen and Shadforth, 2006)

To cut through this problem we use 'age left full-time education' as the basis for our classification of education. Using 'age left full-time education' to group individuals also facilitates the matching between GHS and LFS data, as the highest educational classifications are not the same in the two data sets.

In the main regressions, we classify the sample into two education categories, tertiary (or university) and secondary "equivalents" (including equivalent vocational education) similarly to Katz and Murphy (1992) and Card and Lemieux (2001) for the US. We define workers with tertiary education as those who left full-time education at age 21 or later, and workers with secondary education as those who left full-time education between the ages of 16 and 20 .

In the robustness checks for three education groups, we classify the sample into tertiary (left full-time education at age 21 or later) secondary (left full-time education between age 16 and 20) and less than secondary (left full-time education before age 16)

\section{Wages}

In the main regressions, we group individuals into five yearly and five-year age cells. The midpoints of the time intervals are 1975, 1980, 1985, 1990, 1995, 2000 and 2005. So the 1980 time cell, for example, contains sample observations from 1978 to 1982. Similarly the mid-points of the age intervals are $28,33,38,43,48,53$, and 58 . So, for example, the age 28 group in 1980 contains those aged between 26 and 30 in the mid-point year, that is, all those born from 1950 to 1954. As the data are pooled across five contiguous years, the age group 28 in 1980 also contains all those born between 1950 and 1954 in the surrounding survey years - 24-28 year olds in 1978, 25-29 year olds in 1979, 27-31 year olds in 1981 and 28-32 year olds in 1982. In total, we have 98 cells ( 7 years by 7 age groups by 2 education groups by 2 immigrant status groups)

We use a similar procedure when we present regressions based on three year and three year-age cells. In this case the mid points of the year intervals are 1977, 1980, etc. and the mid points of the age intervals are 28,31 etc.

In the main regressions, we use information on weekly earnings of male full-time employees in order to compute wages by cell, dropping individuals with weekly earnings below $£ 50$ and above $£ 2000$. We use all available data from the GHS spanning 1973 to $2006 .{ }^{16}$

To derive measures of the returns to education by immigrant status, our dependent variable in specifications (9) and (10), we run separate regressions of the log of weekly wages for every individual in each cell (for example native born workers, born in 1945-1949 observed in 1973-1977) on a dummy for university education (left full-time education at age 21 or later) a linear age term (from 26-32) year dummies (from 1973 to 1977) and a London dummy. We run this regression only for those with exactly tertiary or secondary education (as defined above) We use a similar procedure to estimate native wage premia relative to immigrants for each age-timeeducation cell that forms our dependent variable in Equation (8) Table 3 provides information on

\footnotetext{
${ }^{16}$ There was no GHS from April 1997 to March 1998 and from April 1999 to March 2000.
} 
returns to education for natives while Table 4 provides wages of native-born relative to immigrants by skill.

\section{Supply}

In order to compute labor supply for each cell, we use the estimated number of individuals in the population in each age-education-immigrant category. We use the LFS between 1975 and 2007 to estimate the supply. We measure the supply of university graduates as the number of individuals in the sample period that left full-time education at age 21 or later. To compute the supply of "Secondary equivalents" we combine the number of individuals who left full-time education between the ages of 16 and 20 together with the number of individuals who left full-time education before age 16 .

In the main analysis, we weight this second quantity by the average (over all time periods) of the relative wage of individuals with less than secondary education relative to those with exactly secondary in each age-nativity group, similarly to Card and Lemieux (2001). To derive the weights we only take the sample of those with secondary education or less. We run regressions of log wages by cell on a dummy for less than secondary (left full-time education before age 16) over the entire time period (1977 to 2006). In the regressions we also condition for year dummies, a dummy for London and a linear term in age. Regressions are run separately for immigrants and natives. In this way we compute average (over the entire period) wage differentials while controlling for potential compositional effects due the business cycle, lifecycle effects and workers' residential location. Data on the relative supply of natives and immigrants by skill and on the ratio of the two is given in Table 2 . 


\section{TECHNICAL APPENDIX}

\section{The effect of immigration on the wage structure.}

Denote the hypothetical changes in the numbers of immigrant in each education-age cell we are considering by $d \ln \left(M_{e a}\right)$. From (4) and ignoring the time subscript we have for natives:

$$
d \ln \left(W_{e a}^{N}\right)=\frac{1}{\sigma_{E}} d \ln (Y)-\left(\frac{1}{\sigma_{E}}-\frac{1}{\sigma_{A}}\right) d \ln \left(L_{e}\right)-\left(\frac{1}{\sigma_{A}}-\frac{1}{\sigma_{I}}\right) d \ln \left(L_{e a}\right)
$$

And for immigrants that:

$$
d \ln \left(W_{e a}^{M}\right)=\frac{1}{\sigma_{E}} d \ln (Y)-\left(\frac{1}{\sigma_{E}}-\frac{1}{\sigma_{A}}\right) d \ln \left(L_{e}\right)-\left(\frac{1}{\sigma_{A}}-\frac{1}{\sigma_{I}}\right) d \ln \left(L_{e a}\right)-\frac{1}{\sigma_{I}} d \ln \left(M_{e a}\right)
$$

This is the same as for natives but with a final direct impact on the supplies. The components of these two equations can be computed in the following sequential way:

$$
d \ln \left(L_{e a}\right)=\frac{\beta_{e a}^{M} M_{e a}^{\delta}}{\beta_{e a}^{N} N_{e a}^{\delta}+\beta_{e a}^{M} M_{e a}^{\delta}} d \ln \left(M_{e a}\right)=s_{e a}^{M} d \ln \left(M_{e a}\right)
$$

Where $s_{e a}{ }^{M}$ can be shown to be the wage bill share of immigrants in the ea education-age cell. We also have that:

$$
d \ln \left(L_{e}\right)=\frac{\sum_{a} \alpha_{e a} L_{e a}^{\eta} d \ln \left(L_{e a}\right)}{\sum_{a} \alpha_{e a} L_{e a}^{\eta}}=\sum_{a} s_{e a} d \ln \left(L_{e a}\right)
$$

Where $s_{e a}$ can be shown to be the wage bill share of age-group $a$ in education cell $e$. Finally:

$$
d \ln (Y)=\frac{\sum_{e} \theta_{e} L_{e}^{\rho} d \ln \left(L_{e}\right)}{\sum_{e} \theta_{e} L_{e}^{\rho}}=\sum_{e} s_{e} d \ln \left(L_{e}\right)
$$

Where $s_{e}$ can be shown to be the wage bill share of education cell $e$. We use the observed wage bill shares and estimated elasticities of substitution to compute the changes in wages for each cell in response to the observed changes in the number and composition of immigrants.

Because we are interested only in summary statistics we need to weight these cell-specific changes by the employment shares to get the overall changes. 
Figure 1. Immigrant Shares in Male Population of Working Age

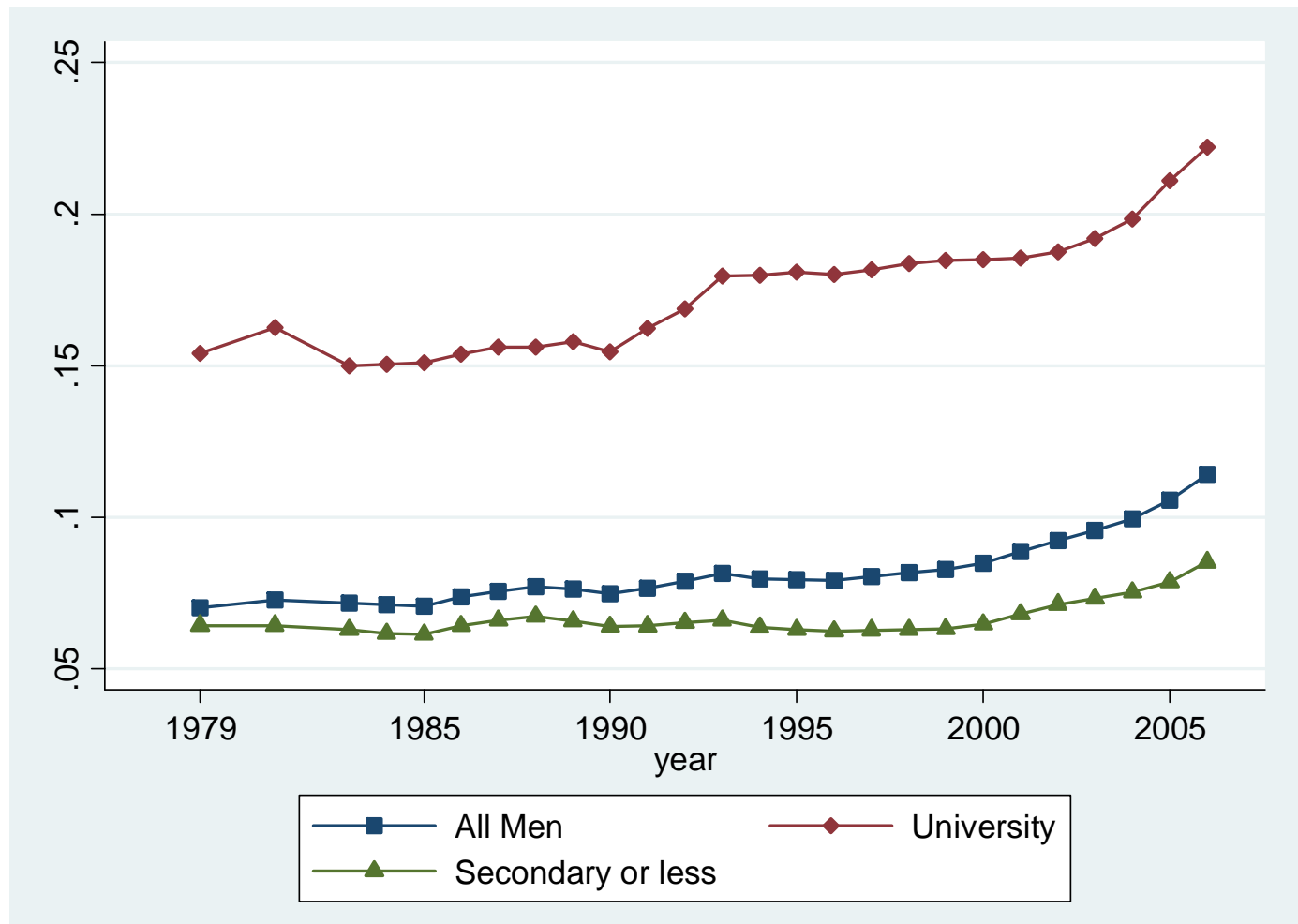

Three year moving averages. Source: LFS

Figure 2. Native-Immigrant Wage Premia and Relative Supply by Age, Time and Education
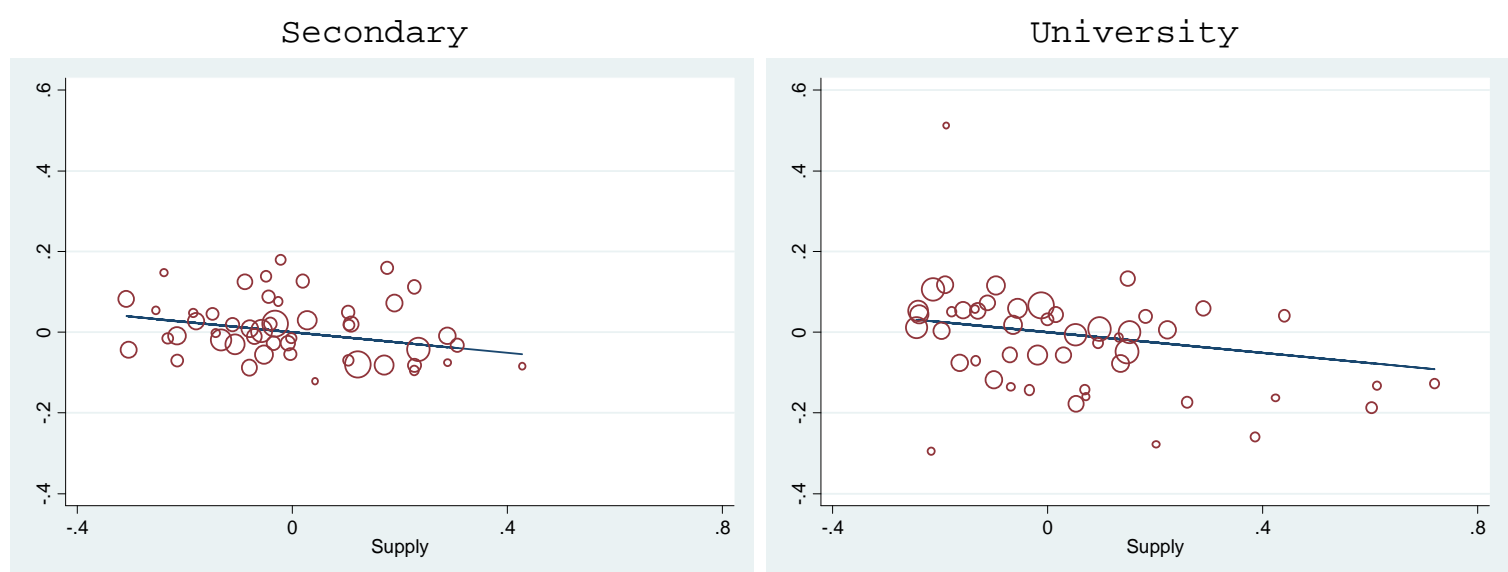

Notes. The graphs give the log native-immigrant wage premia on the vertical axis and the log native-immigrant labor supply on the horizontal axis. Both series are obtained as residuals from a regression on additive age, time and education dummies. The line in the figures refers to the estimated GLS regression line based on row 1 in Table 5. 
Table 1. Male Immigrants and Native-Born Men in Britain

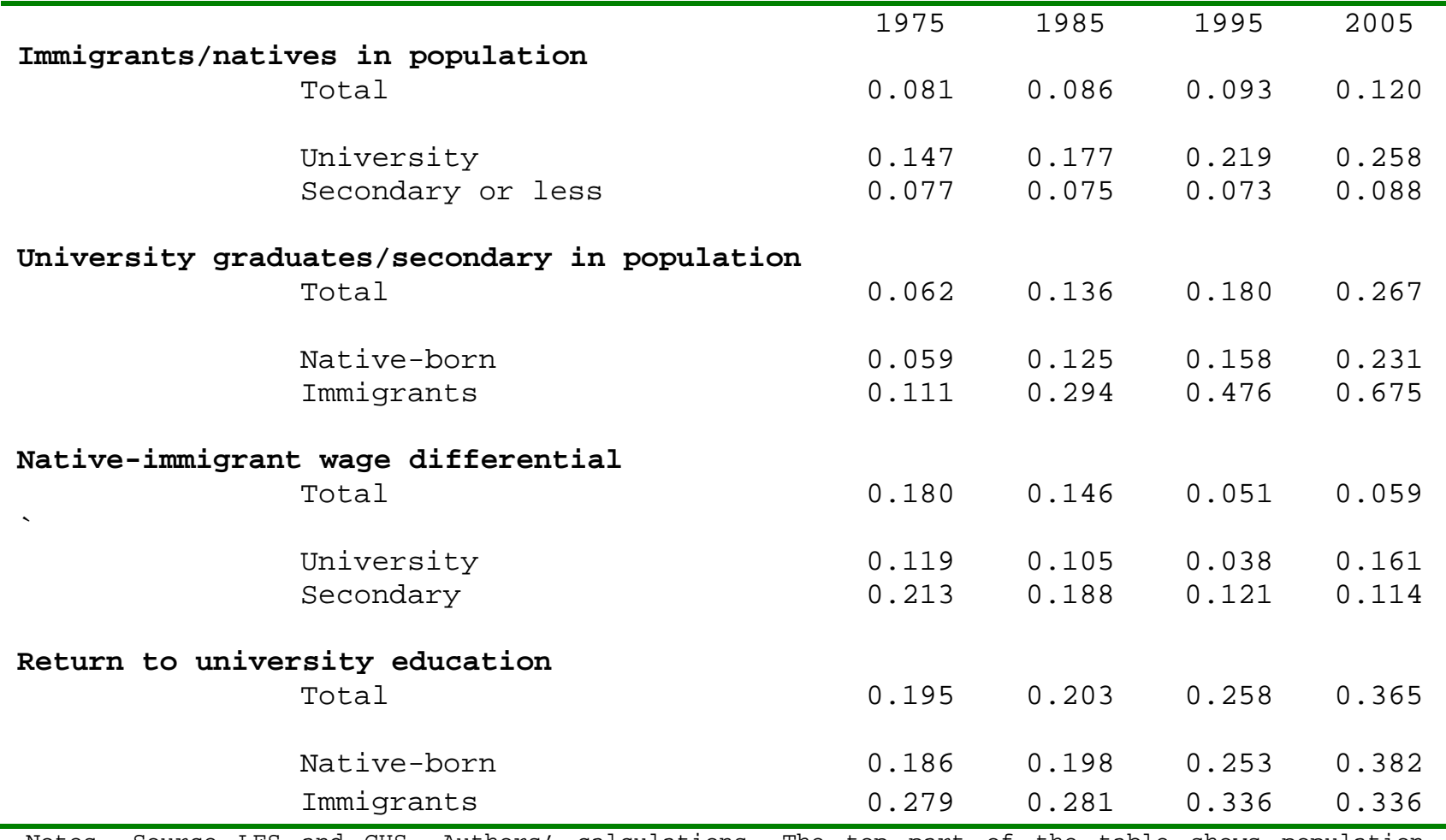

Notes. Source LFS and GHS. Authors' calculations. The top part of the table shows population ratios between immigrants and natives and university and secondary school workers. The bottom part gives wage differentials across the same groups of workers. Returns to education are computed as a regression of log wages on a university dummy, a quadratic in age and a dummy for London. The Native-immigrants wage differentials are computed similarly as a regression of log wages on a native dummy, a quadratic in age and a dummy for London. Regressions include only those with a university degree or a secondary qualification (as defined in the text) See text for details on how supplies of university and secondary equivalents are computed. 
Table 2: Immigrant-native-born population ratio by Age, Time and Education

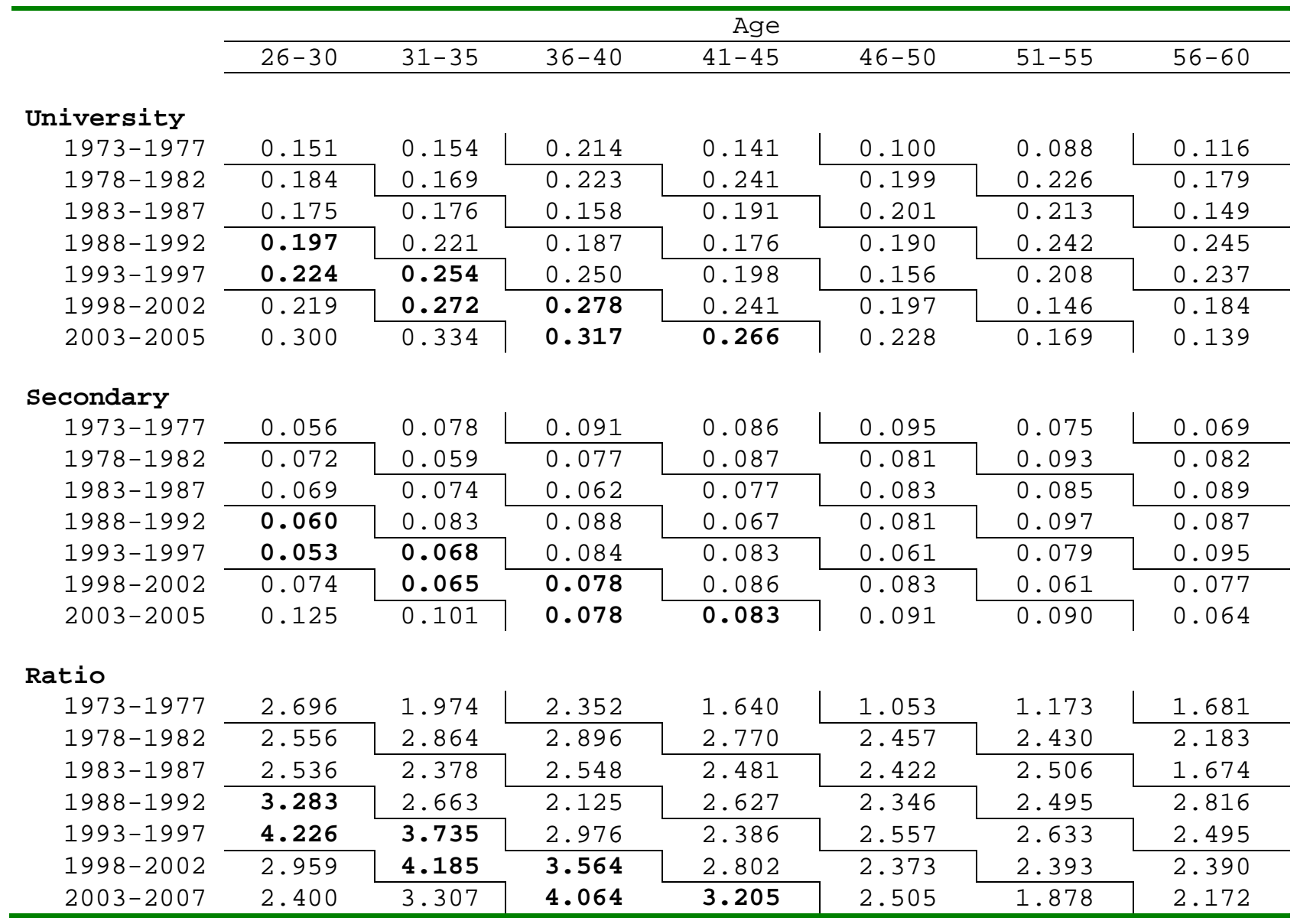

Notes. Source LFS. See also notes to Table 1. 
Table 3: Returns to University/Secondary education by Age, Year and Immigrant Status

\begin{tabular}{|c|c|c|c|c|c|c|c|}
\hline & \multicolumn{7}{|c|}{ Age } \\
\hline & $26-30$ & $31-35$ & $36-40$ & $41-45$ & $46-50$ & $51-55$ & $56-60$ \\
\hline \multicolumn{8}{|l|}{ UK born } \\
\hline $1973-1977$ & $\begin{array}{c}0.118 \\
(0.016)\end{array}$ & $\begin{array}{c}0.189 \\
(0.022)\end{array}$ & $\begin{array}{c}0.204 \\
(0.029)\end{array}$ & $\begin{array}{c}0.247 \\
(0.032)\end{array}$ & $\begin{array}{c}0.209 \\
(0.039)\end{array}$ & $\begin{array}{c}0.244 \\
(0.045)\end{array}$ & $\begin{array}{c}0.272 \\
(0.063)\end{array}$ \\
\hline $1978-1982$ & $\begin{array}{c}0.069 \\
(0.016)\end{array}$ & $\begin{array}{c}0.163 \\
(0.017)\end{array}$ & $\begin{array}{c}0.169 \\
(0.025)\end{array}$ & $\begin{array}{c}0.214 \\
(0.027)\end{array}$ & $\begin{array}{c}0.254 \\
(0.036)\end{array}$ & $\begin{array}{c}0.174 \\
(0.041)\end{array}$ & $\begin{array}{c}0.273 \\
(0.050)\end{array}$ \\
\hline $1983-1987$ & $\begin{array}{c}0.132 \\
(0.018)\end{array}$ & $\begin{array}{c}0.171 \\
(0.019)\end{array}$ & $\begin{array}{c}0.245 \\
(0.023)\end{array}$ & $\begin{array}{c}0.235 \\
(0.033)\end{array}$ & $\begin{array}{c}0.235 \\
(0.041)\end{array}$ & $\begin{array}{c}0.176 \\
(0.050)\end{array}$ & $\begin{array}{c}0.265 \\
(0.069)\end{array}$ \\
\hline $1988-1992$ & $\begin{array}{c}0.249 \\
(0.020)\end{array}$ & $\begin{array}{c}0.256 \\
(0.021)\end{array}$ & $\begin{array}{c}0.212 \\
(0.024)\end{array}$ & $\begin{array}{c}0.196 \\
(0.027)\end{array}$ & $\begin{array}{c}0.179 \\
(0.039)\end{array}$ & $\begin{array}{c}0.309 \\
(0.043)\end{array}$ & $\begin{array}{c}0.270 \\
(0.063)\end{array}$ \\
\hline $1993-1997$ & $\begin{array}{c}0.229 \\
(0.023)\end{array}$ & $\begin{array}{c}0.279 \\
(0.023)\end{array}$ & $\begin{array}{c}\odot .271 \\
(\odot .026)\end{array}$ & $\begin{array}{c}0.245 \\
(0.029)\end{array}$ & $\begin{array}{c}0.212 \\
(0.034)\end{array}$ & $\begin{array}{c}0.300 \\
(0.044)\end{array}$ & $\begin{array}{c}0.212 \\
(0.066)\end{array}$ \\
\hline $1998-20 \odot 2$ & $\begin{array}{c}0.233 \\
(0.026)\end{array}$ & $\begin{array}{c}0.371 \\
(0.027)\end{array}$ & $\begin{array}{c}0.402 \\
(0.028)\end{array}$ & $\begin{array}{c}0.375 \\
(0.031)\end{array}$ & $\begin{array}{c}0.372 \\
(0.037)\end{array}$ & $\begin{array}{c}0.346 \\
(0.043)\end{array}$ & $\begin{array}{c}0.296 \\
(0.069)\end{array}$ \\
\hline $2 \odot \odot 3-2 \odot \odot 7$ & $\begin{array}{c}0.264 \\
(0.025)\end{array}$ & $\begin{array}{c}0.342 \\
(0.025)\end{array}$ & $\begin{array}{c}0.447 \\
(0.029)\end{array}$ & $\begin{array}{c}0.455 \\
(0.032)\end{array}$ & $\begin{array}{c}0.430 \\
(0.035)\end{array}$ & $\begin{array}{c}0.370 \\
(0.036)\end{array}$ & $\begin{array}{c}0.330 \\
(0.047)\end{array}$ \\
\hline \multicolumn{8}{|l|}{ Foreign born } \\
\hline $1973-1977$ & $\begin{array}{c}0.054 \\
(0.051)\end{array}$ & $\begin{array}{c}0.196 \\
(0.055)\end{array}$ & $\begin{array}{c}0.148 \\
(0.074)\end{array}$ & $\begin{array}{c}0.242 \\
(0.078)\end{array}$ & $\begin{array}{c}0.505 \\
(0.093)\end{array}$ & $\begin{array}{c}0.521 \\
(0.113)\end{array}$ & $\begin{array}{c}0.641 \\
(0.142)\end{array}$ \\
\hline $1978-1982$ & $\begin{array}{c}0.049 \\
(0.046)\end{array}$ & $\begin{array}{c}0.194 \\
(0.053)\end{array}$ & $\begin{array}{c}0.205 \\
(0.064)\end{array}$ & $\begin{array}{c}0.155 \\
(0.067)\end{array}$ & $\begin{array}{c}0.236 \\
(0.090)\end{array}$ & $\begin{array}{c}0.200 \\
(0.113)\end{array}$ & $\begin{array}{c}0.477 \\
(0.138)\end{array}$ \\
\hline $1983-1987$ & $\begin{array}{c}\odot .218 \\
(\odot .061)\end{array}$ & $\begin{array}{c}0.147 \\
(0.060)\end{array}$ & $\begin{array}{c}0.337 \\
(0.071)\end{array}$ & $\begin{array}{c}0.237 \\
(0.086)\end{array}$ & $\begin{array}{c}0.441 \\
(0.137)\end{array}$ & $\begin{array}{c}0.192 \\
(0.147)\end{array}$ & $\begin{array}{c}0.624 \\
(0.161)\end{array}$ \\
\hline $1988-1992$ & $\begin{array}{c}0.134 \\
(0.064)\end{array}$ & $\begin{array}{c}0.173 \\
(0.070)\end{array}$ & $\begin{array}{c}0.228 \\
(0.073)\end{array}$ & $\begin{array}{c}0.343 \\
(0.094)\end{array}$ & $\begin{array}{c}0.486 \\
(0.119)\end{array}$ & $\begin{array}{c}0.268 \\
(0.118)\end{array}$ & $\begin{array}{c}0.588 \\
(0.147)\end{array}$ \\
\hline $1993-1997$ & $\begin{array}{c}0.128 \\
(0.075)\end{array}$ & $\begin{array}{c}0.271 \\
(0.070)\end{array}$ & $\begin{array}{c}0.345 \\
(0.079)\end{array}$ & $\begin{array}{c}0.535 \\
(0.084)\end{array}$ & $\begin{array}{c}0.317 \\
(0.119)\end{array}$ & $\begin{array}{c}0.546 \\
(0.126)\end{array}$ & $\begin{array}{c}-0.127 \\
(0.186)\end{array}$ \\
\hline $1998-2002$ & $\begin{array}{c}0.503 \\
(0.078)\end{array}$ & $\begin{array}{c}0.465 \\
(0.076)\end{array}$ & $\begin{array}{c}0.473 \\
(0.080)\end{array}$ & $\begin{array}{c}0.402 \\
(0.088)\end{array}$ & $\begin{array}{c}0.409 \\
(0.120)\end{array}$ & $\begin{array}{c}0.556 \\
(0.150)\end{array}$ & $\begin{array}{c}0.214 \\
(0.166)\end{array}$ \\
\hline $2 \odot \odot 3-2 \odot \odot 7$ & $\begin{array}{c}0.139 \\
(0.063)\end{array}$ & $\begin{array}{c}0.329 \\
(0.067)\end{array}$ & $\begin{array}{c}0.388 \\
(0.082)\end{array}$ & $\begin{array}{c}0.454 \\
(0.082)\end{array}$ & $\begin{array}{c}0.252 \\
(\odot .095)\end{array}$ & $\begin{array}{c}0.372 \\
(0.104)\end{array}$ & $\begin{array}{c}0.404 \\
(0.158)\end{array}$ \\
\hline
\end{tabular}

Notes. Estimated returns to education for immigrants and natives by age and time. Standard errors of the estimated coefficients in brackets. See text for details. Source: GHS. See also notes to Table 1. 
Table 4: Native-Immigrants Wage Differentials by Age, Year and Education

\begin{tabular}{|c|c|c|c|c|c|c|c|}
\hline & \multicolumn{7}{|c|}{ Age } \\
\hline & $26-30$ & $31-35$ & $36-40$ & $41-45$ & $46-50$ & $51-55$ & $56-60$ \\
\hline \multicolumn{8}{|l|}{ University } \\
\hline $1973-1977$ & $\begin{array}{c}0.110 \\
(0.044)\end{array}$ & $\begin{array}{c}0.107 \\
(0.047)\end{array}$ & $\begin{array}{c}0.239 \\
(0.069)\end{array}$ & $\begin{array}{c}0.226 \\
(0.071)\end{array}$ & $\begin{array}{c}-0.005 \\
(0.089) \\
\end{array}$ & $\begin{array}{c}0.087 \\
(0.111)\end{array}$ & $\begin{array}{c}0.049 \\
(0.136) \\
\end{array}$ \\
\hline $1978-1982$ & $\begin{array}{c}0.184 \\
(0.039)\end{array}$ & $\begin{array}{c}0.076 \\
(0.045)\end{array}$ & $\begin{array}{c}0.202 \\
(0.056)\end{array}$ & $\begin{array}{c}0.238 \\
(0.061)\end{array}$ & $\begin{array}{c}0.231 \\
(0.084)\end{array}$ & $\begin{array}{c}0.160 \\
(0.105)\end{array}$ & $\begin{array}{c}0.068 \\
(0.136)\end{array}$ \\
\hline $1983-1987$ & $\begin{array}{c}0.028 \\
(0.053)\end{array}$ & $\begin{array}{c}0.084 \\
(0.048)\end{array}$ & $\begin{array}{c}0.156 \\
(0.059)\end{array}$ & $\begin{array}{c}0.195 \\
(0.076)\end{array}$ & $\begin{array}{c}0.031 \\
(0.0104)\end{array}$ & $\begin{array}{c}0.255 \\
(0.134)\end{array}$ & $\begin{array}{c}-0.082 \\
(0.147)\end{array}$ \\
\hline $1988-1992$ & $\begin{array}{c}0.139 \\
(0.052)\end{array}$ & $\begin{array}{c}0.202 \\
(0.057)\end{array}$ & $\begin{array}{c}0.068 \\
(0.059)\end{array}$ & $\begin{array}{c}0.184 \\
(0.076)\end{array}$ & $\begin{array}{c}0.019 \\
(0.104)\end{array}$ & $\begin{array}{c}0.134 \\
(0.243)\end{array}$ & $\begin{array}{c}0.147 \\
-(0.104)\end{array}$ \\
\hline $1993-1997$ & $\begin{array}{c}0.138 \\
(0.063)\end{array}$ & $\begin{array}{c}0.079 \\
(0.051)\end{array}$ & $\begin{array}{c}0.009 \\
(0.062)\end{array}$ & $\begin{array}{c}-0.092 \\
(0.067)\end{array}$ & $\begin{array}{c}-0.072 \\
(0.094)\end{array}$ & $\begin{array}{c}0.105 \\
-(0.011)\end{array}$ & $\begin{array}{c}0.134 \\
(0.643)\end{array}$ \\
\hline $1998-2002$ & $\begin{array}{c}-0.081 \\
(0.060)\end{array}$ & $\begin{array}{c}0.088 \\
(0.055)\end{array}$ & $\begin{array}{c}0.105 \\
(0.062)\end{array}$ & $\begin{array}{c}0.046 \\
(0.069)\end{array}$ & $\begin{array}{c}0.092 \\
(0.102)\end{array}$ & $\begin{array}{c}0.101 \\
-(0.110)\end{array}$ & $\begin{array}{c}0.173 \\
(0.135)\end{array}$ \\
\hline $2003-2007$ & $\begin{array}{c}0.178 \\
(0.046)\end{array}$ & $\begin{array}{c}0.089 \\
(0.049)\end{array}$ & $\begin{array}{c}0.189 \\
(0.065)\end{array}$ & $\begin{array}{c}0.081 \\
(0.067)\end{array}$ & $\begin{array}{c}0.286 \\
(0.072)\end{array}$ & $\begin{array}{c}0.113 \\
(0.225)\end{array}$ & $\begin{array}{c}0.126 \\
(0.049)\end{array}$ \\
\hline \multicolumn{8}{|l|}{ Secondary } \\
\hline $1973-1977$ & $\begin{array}{c}0.046 \\
(0.030)\end{array}$ & $\begin{array}{c}0.114 \\
(0.037)\end{array}$ & $\begin{array}{c}0.183 \\
(0.044)\end{array}$ & $\begin{array}{c}0.220 \\
(0.049)\end{array}$ & $\begin{array}{c}0.291 \\
(0.050)\end{array}$ & $\begin{array}{c}0.364 \\
(0.053)\end{array}$ & $\begin{array}{c}0.417 \\
(0.079)\end{array}$ \\
\hline $1978-1982$ & $\begin{array}{c}0.164 \\
(0.030)\end{array}$ & $\begin{array}{c}0.107 \\
(0.035)\end{array}$ & $\begin{array}{c}0.238 \\
(0.042)\end{array}$ & $\begin{array}{c}0.179 \\
(0.041)\end{array}$ & $\begin{array}{c}0.213 \\
(0.052)\end{array}$ & $\begin{array}{c}0.185 \\
(0.066)\end{array}$ & $\begin{array}{c}0.273 \\
(0.058)\end{array}$ \\
\hline $1983-1987$ & $\begin{array}{c}0.114 \\
(0.036) \\
\end{array}$ & $\begin{array}{c}0.061 \\
(0.042)\end{array}$ & $\begin{array}{c}0.248 \\
(0.047)\end{array}$ & $\begin{array}{c}0.196 \\
(0.061)\end{array}$ & $\begin{array}{c}0.237 \\
(0.066)\end{array}$ & $\begin{array}{c}0.271 \\
(0.090)\end{array}$ & $\begin{array}{c}0.276 \\
(0.099)\end{array}$ \\
\hline $1988-1992$ & $\begin{array}{c}0.024 \\
(0.042)\end{array}$ & $\begin{array}{c}0.120 \\
(0.046)\end{array}$ & $\begin{array}{c}0.084 \\
(0.050)\end{array}$ & $\begin{array}{c}0.331 \\
(0.065)\end{array}$ & $\begin{array}{c}0.325 \\
(0.073)\end{array}$ & $\begin{array}{c}0.203 \\
(0.073)\end{array}$ & $\begin{array}{c}0.214 \\
(0.093)\end{array}$ \\
\hline $1993-1997$ & $\begin{array}{c}0.037 \\
(0.048)\end{array}$ & $\begin{array}{c}0.072 \\
(0.053)\end{array}$ & $\begin{array}{c}0.083 \\
(0.057)\end{array}$ & $\begin{array}{c}0.199 \\
(0.062)\end{array}$ & $\begin{array}{c}0.032 \\
(0.085)\end{array}$ & $\begin{array}{c}0.235 \\
(0.089)\end{array}$ & $\begin{array}{c}0.304 \\
(0.107)\end{array}$ \\
\hline $1998-2 \odot \odot 2$ & $\begin{array}{c}0.190 \\
(0.059)\end{array}$ & $\begin{array}{c}0.182 \\
(0.060)\end{array}$ & $\begin{array}{c}0.177 \\
(0.059)\end{array}$ & $\begin{array}{c}0.073 \\
(0.066)\end{array}$ & $\begin{array}{c}0.129 \\
(0.076)\end{array}$ & $\begin{array}{c}0.099 \\
(0.110)\end{array}$ & $\begin{array}{c}0.052 \\
(0.133)\end{array}$ \\
\hline $2 \odot \odot 3-2 \odot \odot 7$ & $\begin{array}{c}0.053 \\
(0.050)\end{array}$ & $\begin{array}{c}0.076 \\
(0.053)\end{array}$ & $\begin{array}{c}0.130 \\
(0.059)\end{array}$ & $\begin{array}{c}0.081 \\
(0.058)\end{array}$ & $\begin{array}{c}0.108 \\
(0.072)\end{array}$ & $\begin{array}{c}0.227 \\
(0.070)\end{array}$ & $\begin{array}{c}0.124 \\
(0.112)\end{array}$ \\
\hline
\end{tabular}

Notes. Estimated wage differential between natives and immigrants by age and time. Standard errors of the estimated coefficients in brackets. See text for details. Source: GHS. 
1. Baseline

2. Recent immigrants only

3. Long term immigrants only

4. Saturated specification

5. Heterogeneous effects by education

- secondary

- university

6. Heterogeneous effects by age

- young (26-35)

- middle (36-50)

- older (51-60)

7. Controls for experience rather than age

8. 3 year cells

9. 3 education groups

10. Alternative split between primary and secondary education

11. Alternative split between secondary and tertiary education

12. Ignores efficiency units

13. Unweighted regressions

14. Regressions weighted by cell size

15. Wages weighted by hours (incl. PT workers )

16. Hours instead of population: OLS

17. Hours instead of population: IV

18. Women only

19. Men and women on own group supply

20. Men and women on men and women supply
Estimate

$-0.128 * * *$

$(0.046)$

$-0.216^{*}$

$(0.116)$

$-0.099 * *$

$(0.047)$

-0.204 **

(0.100)

$-0.069$

$(0.064)$

-0.176 ***

(0.058)

Obs. $P$

-0.134 * *

(0.045)

$-0.079$

(0.052)

$-0.011$

(0.076)

$98 \quad .18$

$98 \quad .53$

$98 \quad .45$

98

.36

.41

98

.90

.36

.13

-0.126 ** *

$(0.044)$

$-0.082 *$

$(0.045)$

-0.107 ** *

(0.029)

$-0.159 *$ * *

(0.054)

$-0.075^{*}$

( 0.041$)$

-0.112 * *

(0.051)

-0.185 ** *

( 0.055$)$

-0.219 ***

(0.043)

$-\odot .152$ ***

$(0.048)$

-0.108 ** *

(0.038)

-0.129 ** *

(0.046)

$-0.066$

(0.062)

$98 \quad .97$

220.31

147.46

-0.109 ** *

(0.036)

$98 \quad .56$

$98 \quad .20$

$98 \quad .75$

$98 \quad .30$

98.04

$98 \quad .62$

0.115 ** *

(0.043)

$98 \quad .61$

$98 \quad .98$

$98 \quad .32$

$196 \quad .61$

98.41

The table reports several estimates of equation (8) Each row corresponds to a separate model. All regressions weighted by inverse of estimated variance of dependent variable. Standard errors in brackets. *** Significant at $1 \%$ level, ** Significant at 5\% level, * significant at $10 \%$ level. The last column reports the $p$-value for a test for the equality of each coefficient to the baseline estimate in row 1 . Source GHS and LFS. See text for details. 
Table 6: Occupational Segregation between Immigrants and Natives

\begin{tabular}{|c|c|c|c|c|c|c|c|}
\hline \multirow{6}{*}{$\begin{array}{l}\text { Education } \\
\text { Universit } \\
\text { y } \\
\text { Secondary }\end{array}$} & \multicolumn{7}{|c|}{ Age } \\
\hline & $26-30$ & $31-35$ & $36-40$ & $41-45$ & $46-50$ & $\begin{array}{c}51- \\
55\end{array}$ & $56-60$ \\
\hline & \multicolumn{7}{|c|}{ Duncan Index } \\
\hline & $\odot .251$ & 0.247 & 0.252 & 0.231 & 0.262 & 0.28 & 0.341 \\
\hline & & & & & & 1 & \\
\hline & 0.288 & 0.270 & 0.263 & 0.218 & 0.230 & $\begin{array}{c}0.19 \\
6\end{array}$ & 0.227 \\
\hline & \multicolumn{7}{|c|}{$\%$ in Each Occupation } \\
\hline & Manager/ & Associat & Admin & Skille & Persona & Sale & Elementar \\
\hline & $\begin{array}{c}\text { Professiona } \\
1\end{array}$ & e Prof. & $\cdot$ & $\begin{array}{c}\mathrm{d} \\
\text { Manual }\end{array}$ & $\begin{array}{c}1 \\
\text { Service } \\
\mathrm{s}\end{array}$ & $\mathrm{S}$ & $\mathrm{y}$ \\
\hline $\begin{array}{l}\text { Universit } \\
\text { y Native }\end{array}$ & 70.1 & 17.7 & 3.6 & 4.1 & 0.8 & 1.2 & 2.5 \\
\hline Universit & 61.1 & 14.0 & 4.0 & 5.2 & $2 . \odot$ & 2.3 & 11.4 \\
\hline $\begin{array}{l}\text { y } \\
\text { Immigrant }\end{array}$ & & & & & & & \\
\hline $\begin{array}{l}\text { Secondary } \\
\text { Native }\end{array}$ & 27.1 & 13.1 & 4.3 & 24.1 & 2.2 & 2.6 & 26.6 \\
\hline $\begin{array}{l}\text { Secondary } \\
\text { Immigrant }\end{array}$ & 27.2 & 11.4 & 3.9 & 19.1 & 3.0 & 3.8 & 31.5 \\
\hline
\end{tabular}

Table 7. Estimated Elasticities of Substitution by Immigrant status, Age and Education

\begin{tabular}{|c|c|c|c|c|}
\hline Variable & & $(1)$ & $(2)$ & $(3)$ \\
\hline & & $\begin{array}{l}\text { Native/ } \\
\text { Immigrant }\end{array}$ & $\begin{array}{c}\text { University/ } \\
\text { Secondary } \\
\text { (by age) }\end{array}$ & $\begin{array}{c}\text { University/ } \\
\text { Secondary } \\
\text { (aggregate) }\end{array}$ \\
\hline $\begin{array}{l}\text { Independent variable: } \\
\text { log relative supply }\end{array}$ & & (Step 1) & (Step 2) & (Step 3) \\
\hline $\begin{array}{l}\text { Native-immigrant } \\
\text { (by age and education) }\end{array}$ & $-1 / \sigma_{I}$ & $\begin{array}{c}-0.128 * * * \\
(0.046)\end{array}$ & $\begin{array}{l}-0.144^{*} * \\
(0.061)\end{array}$ & $\begin{array}{l}-0.142 * * \\
(0.065)\end{array}$ \\
\hline $\begin{array}{l}\text { University-Secondary } \\
\text { (by age) }\end{array}$ & $-1 / \sigma_{A}$ & & $\begin{array}{c}-0.196 * * \star \\
(0.037)\end{array}$ & $\begin{array}{c}-0.193 * * * \\
(0.038)\end{array}$ \\
\hline $\begin{array}{l}\text { University-Secondary } \\
\text { (aggregate) }\end{array}$ & $-1 / \sigma_{E}$ & & & $\begin{array}{c}-0.203 * \star * \\
(0.048)\end{array}$ \\
\hline Time trend & S.B.T.C. & ' & & $\begin{array}{l}0.016 * * * \\
(0.002)\end{array}$ \\
\hline Education dummies & & Yes & & \\
\hline Time dummies & & Yes & Yes & \\
\hline Age dummies & & Yes & Yes & Yes \\
\hline Immigrant dummy & & & Yes & Yes \\
\hline
\end{tabular}

Notes: Notes. The Table reports oLS estimates of equations (8) (9) and (10) in the text. Sample size, 98. All regressions weighted by inverse of estimated variance of dependent variable. $\star * *$ Significant at $1 \%$ level, ** Significant at $5 \%$ level, * significant at $10 \%$ level. Source GHS and LFS. See text for details. 
Table 8. Simulations of the Impact of Immigration on Wages

\begin{tabular}{|c|c|c|c|c|c|c|}
\hline & & $\begin{array}{c}\text { Immigrant } \\
\text { age-education } \\
\text { supply } \\
\left(\operatorname{lnS} S_{\text {eat }}\right) \\
\end{array}$ & $\begin{array}{c}\text { Total age- } \\
\text { education } \\
\text { supply }\left(\ln L_{e a t}\right)\end{array}$ & 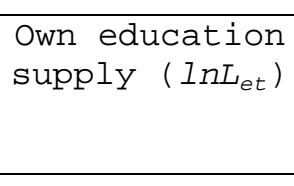 & $\begin{array}{l}\text { Aggregate } \\
\text { supply } \\
\left(\ln Y_{t}\right)\end{array}$ & Total \\
\hline & $\begin{array}{l}\text { Secondary } \\
\text { University }\end{array}$ & $\begin{array}{l}0.04 \\
-0.80\end{array}$ & $\begin{array}{l}0.00 \\
-0.03\end{array}$ & $\begin{array}{l}0.00 \\
-0.01\end{array}$ & $\begin{array}{l}0.01 \\
0.01\end{array}$ & $\begin{array}{c}0.06 \\
-0.83\end{array}$ \\
\hline & $\begin{array}{l}\text { Secondary } \\
\text { University }\end{array}$ & $\begin{array}{l}0.00 \\
0.00\end{array}$ & $\begin{array}{l}0.00 \\
-\odot .03\end{array}$ & $\begin{array}{l}0.00 \\
-0.01\end{array}$ & $\begin{array}{l}0.01 \\
0.01\end{array}$ & $\begin{array}{c}0.01 \\
-0.03\end{array}$ \\
\hline Natives/I & $\begin{array}{l}\text { rants } \\
\text { Secondary } \\
\text { University }\end{array}$ & $\begin{array}{l}-0.04 \\
0.80\end{array}$ & $\begin{array}{l}0.00 \\
0.00\end{array}$ & $\begin{array}{l}0.00 \\
0.00\end{array}$ & $\begin{array}{l}0.00 \\
0.00\end{array}$ & $\begin{array}{l}-0.05 \\
0.80\end{array}$ \\
\hline Universi & $\begin{array}{l}\text { secondary } \\
\text { Migrants } \\
\text { Natives }\end{array}$ & $\begin{array}{l}-0.84 \\
0.00\end{array}$ & $\begin{array}{l}-0.03 \\
-0.03\end{array}$ & $\begin{array}{l}-0.01 \\
-0.01\end{array}$ & $\begin{array}{l}0.00 \\
0.00\end{array}$ & $\begin{array}{l}-0.89 \\
-0.04\end{array}$ \\
\hline
\end{tabular}

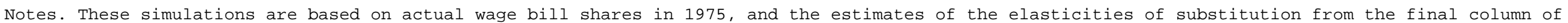
Table 7. The change considered is the change in immigrant supply in each cell that was observed over the period $1975-2005$. 